\title{
Review Article \\ Diagnosis of Parasitic Diseases: Old and New Approaches
}

\author{
Momar Ndao \\ National Reference Centre for Parasitology, McGill University Centre for Tropical Diseases, Montreal General Hospital, \\ 1650 Cedar Avenue R3-137, Montreal, QC, Canada H3G 1A4
}

Correspondence should be addressed to Momar Ndao, momar.ndao@mcgill.ca

Received 31 May 2009; Accepted 29 August 2009

Recommended by Herbert B. Tanowitz

\begin{abstract}
Methods for the diagnosis of infectious diseases have stagnated in the last 20-30 years. Few major advances in clinical diagnostic testing have been made since the introduction of PCR, although new technologies are being investigated. Many tests that form the backbone of the "modern" microbiology laboratory are based on very old and labour-intensive technologies such as microscopy for malaria. Pressing needs include more rapid tests without sacrificing sensitivity, value-added tests, and point-of-care tests for both high- and low-resource settings. In recent years, research has been focused on alternative methods to improve the diagnosis of parasitic diseases. These include immunoassays, molecular-based approaches, and proteomics using mass spectrometry platforms technology. This review summarizes the progress in new approaches in parasite diagnosis and discusses some of the merits and disadvantages of these tests.
\end{abstract}

Copyright (c) 2009 Momar Ndao. This is an open access article distributed under the Creative Commons Attribution License, which permits unrestricted use, distribution, and reproduction in any medium, provided the original work is properly cited.

\section{Introduction}

Currently, the detection and diagnosis of parasite infections rely on several laboratory methods in addition to clinical symptoms, clinical history, travel history, and geographic location of patient. The primary tests currently used to diagnose many parasitic diseases have changed little since the development of the microscope in the 15th century by Antonie van Leeuwenhoek. Furthermore, most of the current tests cannot distinguish between past, latent, acute, and reactivated infections and are not useful for following response to therapy or for prognosis.

Recent developments in new diagnostic tools, however, have opened new avenues for a vast improvement in parasite detection. Firstly, a number of newer serology-based assays that are highly specific and sensitive have emerged, such as the Falcon assay screening test ELISA (FAST-ELISA) [1], Dot-ELISA [2, 3], rapid antigen detection system (RDTS) [4], and luciferase immunoprecipitation system (LIPS) [5]. Secondly, molecular-based approaches such as loopmediated isothermal amplification (LAMP) [6], real-time polymerase chain reaction [7], and Luminex [8] have shown a high potential for use in parasite diagnosis with increased specificity and sensitivity. Thirdly, proteomic technology has also been introduced for the discovery of biomarkers using tissues or biological fluids from the infected host.

The aim of this review is to highlight the potential for these new technologies in parasite diagnosis. For convenience, old and new parasitic diagnostic tools are summarized in Tables 1 and 2. The diagnostic tools offered by the CDC (Centre for Disease Control, Atlanta, USA) and the NRCP (National Reference Centre for Parasitology, Montréal, Canada) are also highlighted in Tables 3 and 4.

\section{Microscopy}

For many years, microscopy has been the only tool available for the detection of parasites through inspection of blood smears [10-14], tissue specimens [15-17], feces, lymph node aspirates $[18,19]$, bone marrow [20], and even cerebrospinal fluid [21]. However, sample preparation for direct observation is time-consuming, labour intensive, and proper diagnosis depends on qualified laboratory technicians. In the case of slide reading, a second independent reading is preferable, but not always required for accurate diagnosis. If need be, divided readings are resolved by a third reader. In endemic regions, where resources are limited, this proves to 
TABLE 1: Diagnostic tools for the detection of specific blood-borne parasitic diseases.

\begin{tabular}{|c|c|c|c|c|c|c|}
\hline & $\begin{array}{c}\text { African } \\
\text { trypanosomiasis } \\
\text { Trypanosoma } \\
\text { brucei }\end{array}$ & $\begin{array}{c}\text { Babesiosis } \\
\text { Babesia } \\
\text { microti }\end{array}$ & $\begin{array}{c}\text { Chagas } \\
\text { disease } \\
\text { Trypanosoma } \\
\text { cruzi }\end{array}$ & $\begin{array}{l}\text { Leishmaniasis } \\
\text { Leishmania } \\
\text { species }\end{array}$ & $\begin{array}{c}\text { Malaria } \\
\text { Plasmodium } \\
\text { species }\end{array}$ & $\begin{array}{l}\text { Toxoplasmosis } \\
\text { Toxoplasma } \\
\text { gondii }\end{array}$ \\
\hline MICROSCOPY & [23] & {$[10]$} & {$[11]$} & {$[12]$} & [13] & - \\
\hline $\begin{array}{l}\text { SEROLOGY- } \\
\text { BASED } \\
\text { ASSAYS } \\
\end{array}$ & - & - & - & - & - & - \\
\hline ELISA & {$[24,25]$} & {$[26]$} & [27-30] & - & - & {$[31]$} \\
\hline FAST-ELISA & - & - & - & - & {$[32,33]$} & - \\
\hline $\begin{array}{l}\text { Dot-ELISA or } \\
\text { Dipstick }\end{array}$ & {$[34]$} & - & {$[35]$} & {$[2,18]$} & - & - \\
\hline RIPA-ELISA & - & - & {$[36,37]$} & - & - & - \\
\hline DHA or IHA & [38] & - & - & {$[18]$} & - & - \\
\hline DFA or IFA & [39] & {$[40,41]$} & - & - & {$[42]$} & {$[43]$} \\
\hline Immunoblot & - & - & {$[44,45]$} & - & - & {$[46]$} \\
\hline PRISM & - & - & {$[47]$} & - & - & - \\
\hline RDT & - & 一 & [48] & - & [49] & 一 \\
\hline $\begin{array}{l}\text { MOLECULAR- } \\
\text { BASED } \\
\text { ASSAYS } \\
\end{array}$ & - & - & - & - & - & - \\
\hline PCR & {$[23]$} & {$[50,51]$} & {$[52-54]$} & {$[55]$} & {$[56]$} & {$[57,58]$} \\
\hline RT-PCR & [59] & - & - & {$[60-62]$} & {$[4,56]$} & {$[63]$} \\
\hline QT-NASBA & - & - & - & {$[64]$} & {$[65,66]$} & - \\
\hline RT-QB-NASBA & - & - & - & - & {$[67]$} & - \\
\hline LAMP & {$[68]$} & - & [69] & - & {$[70-74]$} & - \\
\hline Luminex & - & - & - & - & {$[75]$} & - \\
\hline PCR-ELISA & - & - & - & {$[62,76]$} & {$[77-79]$} & - \\
\hline OC-PCR & {$[80]$} & 一 & 一 & {$[81]$} & - & 一 \\
\hline PROTEOMICS & - & - & - & - & - & - \\
\hline $\begin{array}{l}\text { Mass } \\
\text { Spectrometry } \\
\text { (LDMS, } \\
\text { MALDI-TOF, } \\
\text { SELDI-TOF) } \\
\end{array}$ & {$[82,83]$} & - & - & - & [84-86] & - \\
\hline $\begin{array}{l}\text { FAST-ELISA: Falcor } \\
\text { IFA: direct or indire } \\
\text { for Trypanosomiasi } \\
\text { amplification; RT-Q } \\
\text { oligochromatograph } \\
\text { of flight; SELDI-Tof } \\
\text { time PCR, IB: imm }\end{array}$ & $\begin{array}{l}\text { y screening test; RI } \\
\text { munofluorescence } \\
\text { R: polymerase chain } \\
\text { SBA: real-time qua } \\
\text { ymerase chain reac } \\
\text { ace-enhanced laser } \\
\text { ot. }\end{array}$ & $\begin{array}{l}\text { SA: radioim } \\
\text { DT: rapid d } \\
\text { n; RT-PCR: } \\
\text { e nucleic aci } \\
\text { MS: laser d } \\
\text { ion/ionizati }\end{array}$ & $\begin{array}{l}\text { ecipitation assa } \\
\text { c test; LIPS: luc } \\
\text { e polymerase ch } \\
\text { aced-based amp } \\
\text { n mass spectror } \\
\text { of flight, IFA: i }\end{array}$ & $\begin{array}{l}\text { HA or IHA: direc } \\
\text { e immunoprecip } \\
\text { eaction; QT-NAS } \\
\text { tion; LAMP: loop } \\
\text {; MALDI-ToF: m } \\
\text { nofluorescent ass }\end{array}$ & $\begin{array}{l}\text { direct hemag } \\
\text { system; CAT } \\
\text { dantitative nu } \\
\text { lated isothern } \\
\text { assisted laser } \\
\text { A: Enzyme im }\end{array}$ & $\begin{array}{l}\text { tion assay; DFA or } \\
\text { Agglutination test } \\
\text { id sequenced-based } \\
\text { lification; OC-PCR: } \\
\text { ion/ionization time } \\
\text { ssay, RT-PCR: Real }\end{array}$ \\
\hline
\end{tabular}

be difficult and misdiagnosis can significantly impact patient care. In reality, all major intestinal helminth infections are still solely dependent on microscopy for diagnosis. As for other parasite infections, many are confirmed by the use of microscopy in conjunction to other methods of diagnosis including serology-based assays and more recently molecular-based assays.

\section{Serology-Based Assays}

In situations where biologic samples or tissue specimens are unavailable, serology alone is the gold standard for diagnosis.
Serology-based diagnosis tools can be divided into two categories: antigen-detection assays and antibody-detection assays. These include the enzyme-linked immunosorbent assay (ELISA), also called enzyme immunoassay (EIA), and all its derived tests such as the Falcon assay screening test ELISA (FAST-ELISA) and the dot-ELISA. Other assays include the hemagglutination (HA) test, indirect or direct immunofluorescent antibody (IFA or DFA) tests, complement fixation (CF) test, and immunoblotting and rapid diagnostic tests (RDTs).

Although the ease of use and turnaround times for serologic assays are similar to microscopy, serology-based 
TABle 2: Diagnostic tools for the detection of specific intestinal parasitic diseases.

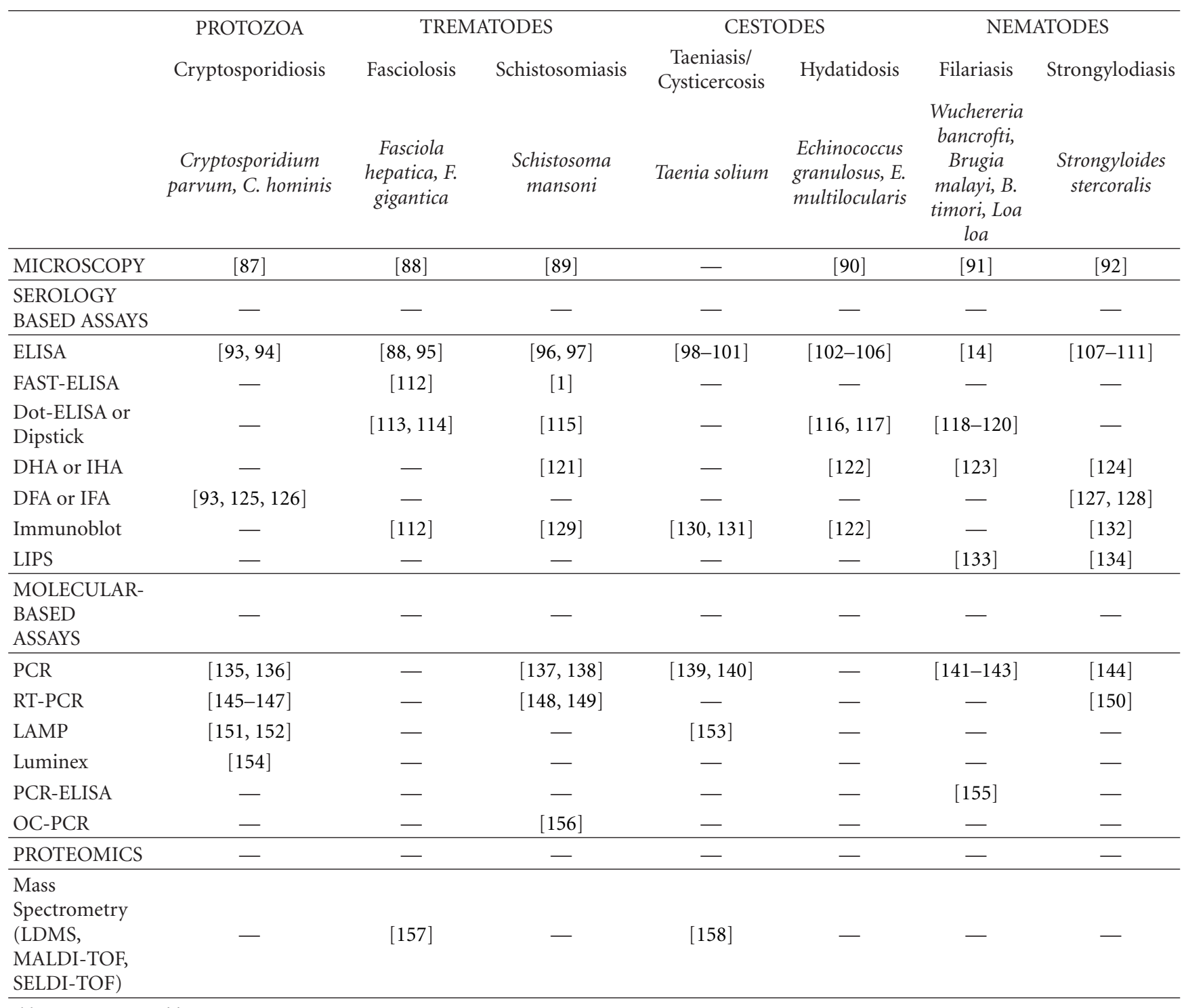

Abbreviations: see Table 1.

TABLE 3: Diagnostic tools for the detection of specific blood-borne parasitic diseases offered by the CDC and the NRCP.

\begin{tabular}{|c|c|c|c|c|c|c|}
\hline & $\begin{array}{c}\text { African } \\
\text { trypanosomiasis }\end{array}$ & Babesiosis & Chagas disease & Leishmaniasis & Malaria & Toxoplasmosis \\
\hline & $\begin{array}{l}\text { Trypanosoma } \\
\text { brucei species }\end{array}$ & Babesia microti & Trypanosoma cruzi & $\begin{array}{l}\text { Leishmania } \\
\text { species }\end{array}$ & $\begin{array}{c}\text { Plasmodium } \\
\text { species }\end{array}$ & $\begin{array}{l}\text { Toxoplasma } \\
\text { gondii }\end{array}$ \\
\hline $\begin{array}{c}\text { CDC } \\
\text { DIAGNOSTIC } \\
\text { TOOLS }\end{array}$ & Microscopy & $\begin{array}{c}\text { Microscopy IFA, } \\
\text { PCR }\end{array}$ & $\begin{array}{c}\text { Microscopy } \\
\text { culture, IFA, EIA }\end{array}$ & $\begin{array}{l}\text { Microscopy, } \\
\text { Culture, IFA }\end{array}$ & $\begin{array}{c}\text { Microscopy } \\
\text { PCR, IFA }\end{array}$ & $\begin{array}{c}\text { Microscopy IFA, } \\
\text { EIA }\end{array}$ \\
\hline $\begin{array}{c}\text { NRCP } \\
\text { DIAGNOSTIC } \\
\text { TOOLS }\end{array}$ & $\begin{array}{c}\text { Microscopy, } \\
\text { culture, CATT, } \\
\text { PCR }\end{array}$ & Microscopy, IFA & $\begin{array}{c}\text { Microscopy, } \\
\text { culture, EIA, } \\
\text { RT-PCR }\end{array}$ & $\begin{array}{l}\text { Microscopy, } \\
\text { Culture, IFA, } \\
\text { RT-PCR }\end{array}$ & $\begin{array}{l}\text { Microscopy, } \\
\text { IFA, IB, PCR }\end{array}$ & RT-PCR \\
\hline
\end{tabular}

CDC: Centre for Disease Control, Atlanta, Georgia, USA. NRCP: National Reference Centre for Parasitology, Montreal General Hospital, Montreal, Quebec, Canada. Abbreviations: see Table 1. 


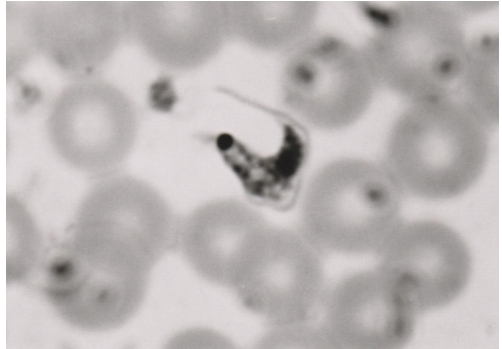

(a)

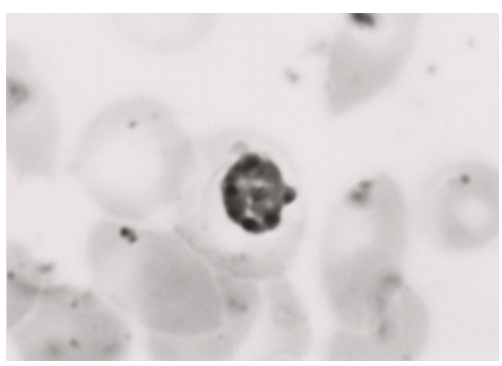

(b)

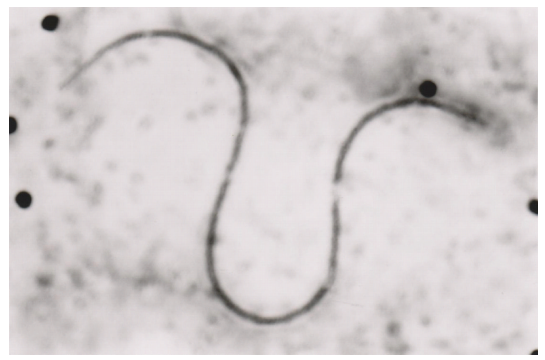

(c)

Figure 1: Microscopy. Comparison of Trypanosoma cruzi trypomastogote (a) with Plasmodium malariae schizont (b) and with microfilaria (c: Mansonella perstans) in squirrel monkey blood smear. Giemsa stain: 70x oil-immersion objective (a) and (b) and 27.2x objective (c), adapted with permission of Comparative Medicine from [9].

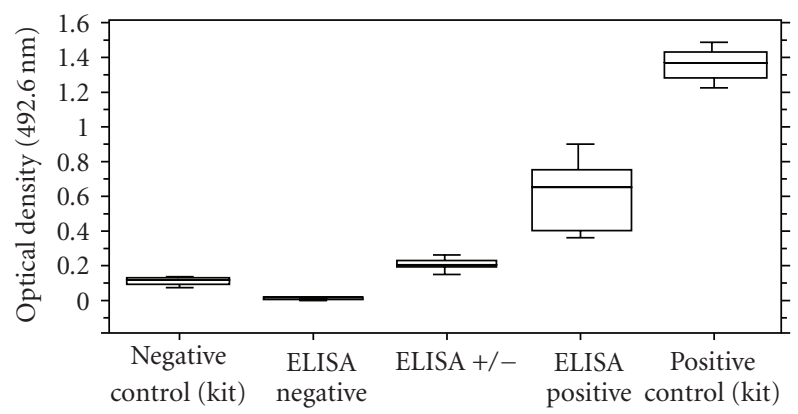

Figure 2: Serology-based assays: ELISA. Enzyme-linked immunosorbent assay (ELISA) absorbance values for antibodies to T. cruzi in monkey samples. Median values are indicated by horizontal lines within the boxes; the 25th and 75th percentiles are enclosed by the boxes; the 5th and 95th percentiles are enclosed by the bars outside the boxes. Adapted with permission of Comparative Medicine from [9].

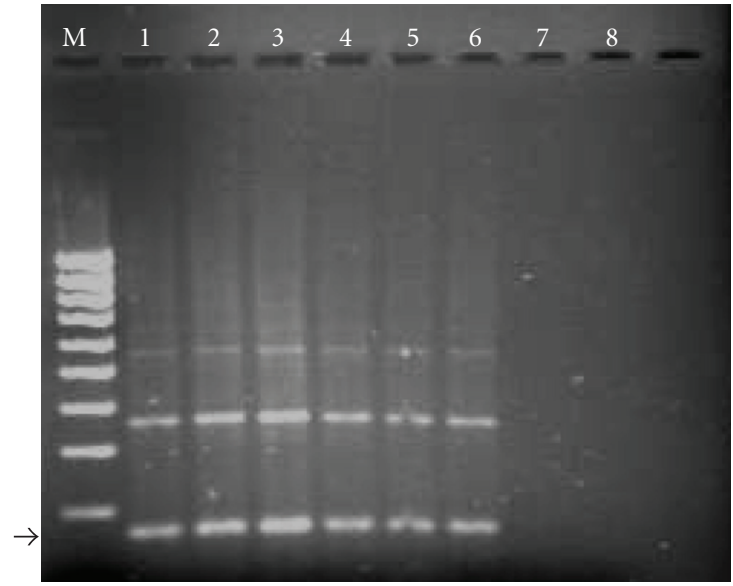

Figure 3: Molecular-based assay: PCR. Example of PCR results obtained for seven monkey samples, using the TCRUZ primers. Blood samples were processed as described in Materials and Methods. The PCR products were electrophoresed in a 2\% agarose gel and stained with ethidium bromide. The $168 \mathrm{bp}$ band (arrow) is the expected T. cruzi-specific product. The 360 and $550 \mathrm{bp}$ are also specific products resulting from amplification of two or three of the 195 bp repeats found in tandem arrays in the T. cruzi genome. Lanes 1 to 6 contain the amplification products of DNA from T. cruzi-infected monkeys; 7 , blood from noninfected monkey; 8 , negative control (distilled water); and M, 100 bp ladder, adapted, with permission of Comparative Medicine from [9].

assays are more sensitive and specific. It becomes important for individuals whose blood smears do not permit identification of the parasite (e.g., differentiating between Babesia and Plasmodium) [159] or for patients exhibiting lowparasitemia and/or who are asymptomatic (e.g., Chagasic patients) [54]. Classifying an infected asymptomatic patient as negative could lead to transmission of the parasite during blood transfusions or organ transplants. In the case of Fasciola infection, serology tests have also been shown to be useful in the confirmation of chronic fascioliasis when egg production is low or sporadic [112]. Finally, having these tests readily available allows for the monitoring of parasite clearance following therapy.

3.1. Falcon Assay Screening Test ELISA (FAST-ELISA). The Falcon assay screening test ELISA (FAST-ELISA) consists of using synthetic and recombinant peptides to evaluate antibody responses to an antigen [1]. In the past, the method has been applied to the study of malaria [32], fasciolosis [112], schistosomiasis (reviewed in [160]), and taeniasis [161]. However, this technique is subjected to the same drawbacks as most serology-based tests. Antibodies raised against a peptide from one parasite protein may cross-react with proteins from other species. Moreover, antibodies raised against a peptide may react in some assays but not in others and some regions of a peptide may be more immunogenic than others. No recent studies have been published on the use of the FAST-ELISA for the diagnosis of parasitic infections. 
TABLE 4: Diagnostic tools for the detection of specific intestinal parasitic diseases offered by the CDC and the NRCP.

\begin{tabular}{|c|c|c|c|c|c|c|c|}
\hline & \multirow{2}{*}{$\begin{array}{c}\text { PROTOZOA } \\
\text { Cryptosporidiosis }\end{array}$} & \multicolumn{2}{|c|}{ TREMATODES } & \multicolumn{2}{|c|}{ CESTODES } & \multicolumn{2}{|c|}{ NEMATODES } \\
\hline & & Fasciolosis & Schistosomiasis & $\begin{array}{c}\text { Taeniasis } \\
\text { Cysticercosis }\end{array}$ & Hydatidosis & Filariasis & Strongylodiasis \\
\hline & $\begin{array}{l}\text { Cryptosporidium } \\
\text { parvum, C. hominis }\end{array}$ & $\begin{array}{c}\text { Fasciola } \\
\text { hepatica, F. } \\
\text { gigantica }\end{array}$ & $\begin{array}{l}\text { Schistosoma } \\
\text { mansoni }\end{array}$ & Taenia solium & $\begin{array}{l}\text { Echinococcus } \\
\text { granulosus, E. } \\
\text { multilocularis }\end{array}$ & $\begin{array}{c}\text { Wuchereria } \\
\text { bancrofti, } \\
\text { Brugia } \\
\text { malayi, B. } \\
\text { timori, Loa } \\
\text { loa }\end{array}$ & $\begin{array}{l}\text { Strongyloides } \\
\text { stercoralis }\end{array}$ \\
\hline $\begin{array}{l}\text { CDC DIAG- } \\
\text { NOSTIC } \\
\text { TOOLS }\end{array}$ & $\begin{array}{c}\text { Microscopy, EIA, } \\
\text { PCR, RT-PCR }\end{array}$ & - & $\begin{array}{l}\text { Microsocopy, } \\
\text { FAST-ELISA, IB }\end{array}$ & Immunoblot, & IB & $\begin{array}{c}\text { Microscopy, } \\
\text { EIA }\end{array}$ & Microscopy, EIA \\
\hline $\begin{array}{l}\text { NRCP DIAG- } \\
\text { NOSTIC } \\
\text { TOOLS }\end{array}$ & Microscopy, EIA & $\begin{array}{l}\text { Microscopy, } \\
\text { EIA }\end{array}$ & Microscopy, EIA & IB & EIA & $\begin{array}{l}\text { Microscopy, } \\
\text { EIA }\end{array}$ & $\begin{array}{l}\text { Microscopy, } \\
\text { culture, EIA, IB }\end{array}$ \\
\hline
\end{tabular}

CDC: Centre for Disease Control, Atlanta, Georgia, USA. NRCP: National Reference Centre for Parasitology, Montreal General Hospital, Montreal, Quebec, Canada.

3.2. Dot-ELISA. The main difference between the regular ELISA and the dot-ELISA lies in the surface used to bind the antigen of choice. In the dot-ELISA, the plastic plate is replaced by a nitrocellulose or other paper membrane onto which a small amount of sample volume is applied. The choice of binding matrix greatly improved the specificity and sensitivity of the assay by reducing the binding of nonspecific proteins usually observed when plastic binding matrixes are used. The principle is similar to the immunoblot. The dotted membrane is incubated first with an antigen-specific antibody followed by an enzyme-conjugated anti-antibody. The addition of a precipitable, chromogenic substrate causes the formation of a colored dot on the membrane which can be visually read [2]. The benefits of this technique include its ease of use, its rapidity, and the ease of result interpretation. It is fast, and cost-effective and more importantly can be used in the field (e.g., as a dipstick). For all these reasons, the DotELISA has been and still is extensively used in the detection of human and animal parasitic diseases, including amebiasis, babesiosis, fascioliasis, cutaneous and visceral leishmaniasis, cysticercosis, echinococcosis, malaria, schistosomiasis, toxocariasis, toxoplasmosis, trichinosis, and trypanosomiasis (all reviewed in [3]). In the last few years, published studies have demonstrated the use of the dot-ELISA for the detection of Fasciola gigantica [113], Haemonchus contortus [162], Theileria equi [163], Trypanosoma cruzi [164], and Trypanosoma brucei [34]. In the latter study the researchers were able to demonstrate that the dot-ELISA had better sensitivity and specificity than the ELISA in the detection of antineurofilament and antigalactocerebrosides antibodies in cerebrospinal fluid of subjects infected with African trypanosomes. They attributed the greater sensitivity and specificity of the dot-ELISA to the use of the nitrocellulose membrane and showed that their assay was successfully reproducible in the field.
3.3. Rapid Antigen Detection System (RDTS). Rapid antigen detection tests (RDTs) based on immunochromatographic antigen detection have been implemented in many diagnostic laboratories as an adjunct to microscopy for the diagnosis of malaria. RDTs consist of capturing soluble proteins by complexing them with capture antibodies embedded on a nitrocellulose strip. A drop of blood sample is applied to the strip and eluted from the nitrocellulose strip by the addition of a few drops of buffer containing a labeled antibody. The antigen-antibody complex can then be visualized directly from the membrane [4].

Since the appearance of the first RDTs in the 990s, major improvements have been made to the technique, making the use of RDTs in rural endemic regions feasible. RDTs are now rapid, stable at temperatures up to $40^{\circ} \mathrm{C}$, easy to use, and cost-effective thereby providing many advantages over traditional microscopic methods [165]. RDTs are useful in the identification of $P$. falciparum and $P$. vivax infections but cannot be used to identify $P$. malariae and $P$. ovale infections [4]. In addition, they are useless at detecting very low-density infections. PCR-based approaches remain the tool of choice in that situation. More than 80 RDTs exist for the detection of either histidine-rich protein (HRP) specific to $P$. falciparum or species-specific isotypes of lactate dehydrogenase (LDH) [49]. However, as reported by Murray et al. [165] only 23 have met the WHO's criteria for international marketing.

Malaria RDTs have recently been introduced in African countries to help prevent misdiagnosis of malaria infections and to subsequently reduce the practice of presumptive treatment [49]. In fact, the tendency to treat slide-negative samples with antimalarials is still a common phenomenon. This practice causes concern not only for the patient's health care but also to the costs it generates in prescribing the more expensive antimalarial sulfadoxine/pyrimethamine and artemisinin-based combinations [165]. Finally, misuse of antimalarials could lead to the appearance of drugresistant strains. 
3.4. Luciferase Immunoprecipitation System (LIPS). The luciferase immunoprecipitation system (LIPS) is a modified ELISA-based assay in which serum containing antigenspecific antibodies can be identified by measuring light production. Basically, an antigen of choice is fused to the enzyme reporter Renilla luciferase (Ruc) and expressed as a Ruc-fusion in mammalian cells to allow for mammalianspecific posttranslational modifications. The crude protein extract is then incubated with the test serum and protein A/G beads. During the incubation, the Ruc-antigen fusion becomes immobilized on the A/G beads, which allows the antigen-specific antibody to be quantitated by washing the beads and adding coelenterazine substrate and measuring light production [5].

In recent years, LIPS has been successfully applied for the identification of sera samples infected with Strongyloides stercoralis (using a Ruc-NIE fusion) [134] and Loa loa (using a Ruc-LlSXP-1 fusion) [133]. Some of the advantages of the LIPS technology include its rapidity and accuracy in detecting infected patients. Sensitivity is improved in part by the use of mammalian cells which produce fusion antigens free of contaminating bacterial proteins. In addition, low backgrounds are produced compared to the ELISA. This greatly facilitates the separation between negative and positive samples. In addition, the Strongyloides LIPS based on the NIE antigen showed greater specificity than the ELISA as no cross-reaction was observed with serum from filarialinfected subjects [134].

A LIPS assay can be performed in 2.5 hours. Burbelo et al. 2008 [133] were able to obtain 100\% specificity and sensitivity when performing an LIPS assay based on the Loa loa SXP-1 antigen with only a small-degree of crossreactivity with a few Onchocerca volvulus- and Wuchereria bancrofti-infected patient sera. By decreasing the incubation times of a normal LIPS assay, they were able to minimize cross-reaction. Many of the O. volvulus sera samples tested as positive with the LIPS assay were negative using this 15minute LIPS assay also called QLIPS. Of interest for the application of this technique in the field is the observation that blood obtained by finger-prick (contaminated with red blood cells and other components) did not interfere with the LIPS assay. Further studies will be useful in exploring and validating the accuracy and potential usefulness of the LIPS and QLIPS assays in the field.

As discussed, immunodiagnostics tests have some serious limitations. Parasitic diseases such as amebiasis, cryptosporidiosis, filariasis, giardiasis, malaria, cysticercosis, schistosomiasis, and African trypanosomiasis do not have commercially or FDA approved antibody detection tests for their diagnosis. Experimental results have been too variable due to the type of antigen preparations used (e.g., crude, recombinant purified, adult worm, egg) and also because of the use of nonstandardized test procedures. Cross-reaction leading to false-positives and misdiagnosis is also a problem, especially in regions where more than one parasite is endemic. Despite the fact that some parasites in South America share common epitopes, it is common to see coinfection with Trypanosoma cruzi and Leishmania species [166]. It is also a problem in Africa, where cross-reactivity exists between filarial and other helminth antigens [133]. To a lesser extent but nonetheless important is the inability of antibody-detection tests to differentiate between past and currently active infections [167]. Furthermore, antibodydetection tests cannot be used in parasitic infections that do not develop a significant antibody response. This has been observed in some individuals carrying Echinococcus cysts [168] or during cutaneous leishmaniasis (http://www.dpd.cdc.gov/dpdx/HTML/Leishmaniasis.htm). Similarly, in the case of African trypanosomiasis diagnosis, such tests are of limited use because seroconversion occurs only after the onset of clinical symptoms [83].

For all these reasons, there is still a need to improve on the current diagnosis approaches available. Since the advent of the polymerase chain reaction (PCR), parasitologists have turned to molecular-based approaches in the hopes to better the existing diagnosis tools.

\section{Molecular-Based Approaches}

4.1. Nucleic Acid-Based Approaches. The many limitations of microscopy and serology-based assays have influenced parasitologists towards the use of gene amplification methods made possible with the advent of the polymerase chain reaction (PCR). Besides the traditional PCR, including nested and multiplexed PCR, we have seen the implementation of the real-time PCR (RT-PCR) for the detection of several parasitic infections. Newer technologies such as loop-mediated isothermal amplification and Luminex-based assays have also emerged as possible new approaches for the diagnosis of parasitic diseases.

Molecular-based approaches based on nucleic acids offer greater sensitivity and specificity over the existing diagnostic tests. They permit the detection of infections from very low parasitized samples including those from asymptomatic patient's samples [169]. Moreover, multiplexed PCR allows for the detection of multiple sequences in the same reaction tube proving useful in the diagnosis of several parasitic infections simultaneously [170].

4.2. Real-Time Polymerase Chain Reaction (RT-PCR). RTPCR system unlike conventional PCR, allow for the quantification of the original template's concentration through the use of various fluorescent chemistries, such as Sybergreen, Taqman probes, fluorescence resonance energy transfer (FRET), and Scorpion primers [7]. The concentration is measured through comparison to standard curves. This eliminates the need to visualize the amplicons by gel electrophoresis thereby greatly reducing the risk of contamination and the introduction of false-positives. When multiplexed, RT-PCR allows for the high-throughput analysis of different sequences in one single-closed tube reaction [171]. Using multiplexed RT-PCR, Shokoples et al. [4] were able to identify the four human Plasmodium species (falciparum, vivax, malariae, and ovale) in a single reaction tube even in very low parasitized samples. Running the multiplex assay not only reduced the cost per test but also allowed for a rapid turnaround time, the assay taking only three hours to 
complete. It is a clear advantage over microscopy which is labour intensive and time-consuming with slow turnaround times especially during high-throughput settings. Similarly, multiplexed RT-PCR proved useful in differentiating drugsensitive strains of malaria [172]. This is important for proper antimalarial prescription. In another example, Diez et al. [54] were able to detect the presence of T. cruzi infection following heart transplants using PCR. This allowed immediate treatment of the patients before reactivation of Chagas disease could occur. These examples demonstrate that efficient and early diagnosis can directly impact patients care and that PCR-based approaches have the potential to help in making the right choice for treatment.

Although DNA-based methods have shown excellent sensitivity and specificity, the introduction of these methods in daily laboratory practice is still uncommon especially in rural endemic regions. In addition, as observed with many serology-based assays, PCR-based methods also suffer by the lack of standardization [22]. DNA extraction, choice of primer sets, and use of various amplification protocols are all factors that may cause this diversification in results [173]. Adding an automated DNA extraction step would certainly improve PCR assays for use in the diagnosis of parasitic diseases.

4.3. Loop-Mediated Isothermal Amplification (LAMP). Loopmediated isothermal amplification (LAMP) is a unique amplification method with extremely high specificity and sensitivity able to discriminate between a single nucleotide difference [6]. It is characterised by the use of six different primers specifically designed to recognise eight distinct regions on a target gene, with amplification only occurring if all primers bind and form a product [174]. In the past, LAMP has been successfully applied for the rapid detection of both DNA and RNA viruses such as the West Nile [175] and SARS viruses [176]. Recently, parasitologists have adapted the LAMP approach for the detection of several parasitic diseases including the human parasites Entamoeba [177], Trypanosoma [68], Taenia [153], Plasmodium [70], and Cryptosporidium [152], the animal parasites Theilera [178] and Babesia [178, 179], and even to the identification of vector mosquitoes carrying Plasmodium [73] and Dirofilaria immitis [180] parasites. Most of these studies have brought to light the many advantages of this method over the common PCR technique.

Unlike a regular PCR reaction, LAMP is carried out at a constant temperature (usually in the range of $60-65^{\circ} \mathrm{C}$ ). This unique feature not only results in higher yields, but also eliminates the need to buy a thermal cycler and shortens the reaction time by eliminating time lost during thermal changes. In addition, the reaction can be carried out without extracting the DNA from the collected samples as shown in the case of RIME, a nonautonomous retroelement found in Trypanosoma brucei rhodesiense and T. b. gambiense [68]. In 35 minutes, using a simple water bath, RIME LAMP was able to detect both T. b. gambiense and T. $b$. rhodesiense directly from blood, serum, and CSF samples. More importantly, the study has shown reproducibility in the field. In addition to the above advantages, LAMP reactions are easy to set up, and results can readily be assessed. The sample of interest is mixed with primers, substrates, and a DNA polymerase capable of strand displacement in a microcentrifuge tube. During the reaction, large amounts of pyrophosphate ions are produced, leading to the formation of a white precipitate [181]. This turbidity is proportional with the amount of DNA synthesized therefore one can assess the reaction by real-time measurement of turbidity or more importantly, simply through the naked-eye.

For all these reasons, the future adoption of LAMP as a diagnostic tool for parasite infections in rural endemic regions shows promise. Furthermore, as more groups apply LAMP to the field of parasitology, we will see the appearance of LAMP-modified assays that meet specific detection needs. For example, in a recent study on bovine Babesia [182], a multiplex-LAMP (mLAMP) assay was developed to simultaneously detect $B$. bovis and B. bigemina from DNA extracted from blood spotted on filter paper. Similarly, Han et al. [71] implemented a LAMP assay based on the 18S rRNA gene for the detection of the four human Plasmodium species (falciparum, vivax, malariae, and ovale). LAMP had a similar sensitivity and a greater specificity than nested PCR, yielding similar results but at a faster turnaround time. Their results are consistent with other studies demonstrating the rapidity and the improved specificity and sensitivity obtained using the LAMP assay.

4.4. Luminex $x$ MAP Technology. Luminex technology is a bead-based flow-cytometric assay that allows the detection of various targets simultaneously (http://www.luminexcorp.com/). The microsphere beads can be covalently bound to antigens, antibodies, or oligonucleotides that will serve as probes in the assay. Up to 100 microspheres are available each emitting unique fluorescent signals when excited by laser therefore allowing the identification of different targets [183]. Adapted to the study of parasites, the Luminex assay could identify multiple organisms or different genotypes of one particular organism during the same reaction utilizing very low volume. The approach could prove useful in the study of antigenic diversity and drugresistance alleles and for the diagnosis of parasitic diseases.

Luminex was applied to the study of Cryptosporidium [154]. C. hominis and C. parvum cannot be distinguished using antigen detection or serology assays. Only DNA-based approaches have been successful in doing so by exploiting the single nucleotide difference in the microsatellite- 2 region (ML-2) of both species [154]. Ultimately DNA sequencing is the diagnosis tool of choice but it is costly, labour-intensive and time-consuming. In a recent study, Bandyopadhyay et al. [154] successfully detected and distinguished $C$. hominis and C. parvum in 143 DNA extracts using Luminex technology by using oligonucleotide probes specific to the ML-2 regions of each species. Turnaround time was about 5 hours making this assay not only much faster but also less expensive than PCR followed by DNA sequencing. It also proved to be $100 \%$ specific and more sensitive than a direct fluorescent antibody (DFA) test, a method routinely 
used to identify Cryptosporidium and Giardia species. Note that DFA cannot differentiate between $C$. hominis and $C$. parvum.

Similarly in other research, Luminex technology was able to detect all-blood stage parasite levels of the four human Plasmodium species (falciparum, vivax, malariae, and ovale) simultaneously [75]. This study demonstrated that Luminex technology can improve the speed, the accuracy, and the reliability of other PCR methods. For example, the need for gel electrophoresis to differentiate the LDR products representing the four human Plasmodium species is eliminated. Second, all samples are handled simultaneously and continuously through a 96-well plate format from DNA extraction all through data analysis. The process is automated and therefore uniformity can be achieved. Finally, the high-throughput capability of the Luminex system confers it a clear advantage over the use of labour-intensive microscopy for large scale studies.

4.5. Proteomics. Since proteins are the main catalysts, structural elements, signalling messengers, and molecular machines of biological tissues, proteomic studies are able to provide substantial clinical relevance. Proteins can be utilized as biomarkers for tissues, cell types, developmental stages, and disease states as well as potential targets for drug discovery and interventional approaches. The next generation of diagnostic tests for infectious diseases will emerge from proteomic studies of serum and other body fluids. Recent advances in this area are attributable largely to the introduction of mass spectrometry platforms capable of screening complex biological fluids for individual protein and peptide "biomarkers." Proteomic strategy can identify proteins in two ways: bottom-up and top-down approaches. In the former, the proteins in a biological fluid are proteolytically shattered into small fragments that can be easily sequenced and the resultant spectra are compared with those in established peptide databases. This is the protein equivalent of "shotgun" genomics. Bottom-up strategies are difficult to quantitate and cannot identify modified molecules (e.g., alternately spliced, glycosylated). Since each open reading frame in the human genome is thought to generate at least 10 modified proteins, this issue is a major limitation.

The classic top-down strategy is 2-dimensional gel electrophoresis. Top-down strategies seek to identify proteins and peptides (and their natural variants) in complex biological fluids. Two-dimensional (2D) gel electrophoresis was first described in 1975. With this method, proteins are resolved in the first dimension based on $\mathrm{pH}$ (a process called isoelectric focusing) and in the second dimension by their molecular weight. This technique is labor intensive, and low throughput and requires large amounts of sample. Such limitations have encouraged the search for improved approaches. Other techniques used for the expression analysis of proteins are matrix-assisted laser desorption ionization time-of-flight mass spectrometry (MALDI-TOF MS), surface-enhanced laser desorption ionization time of flight mass spectrometry (SELDI-TOF MS), liquid chromatography combined with MS (LC-MS-MS), isotope-coded affinity tags (ICAT), and isotope tags for relative and absolute quantification (iTRAQ).

The development of automated, high-throughput proteomic technologies such as MALDI-TOF and SELDI-TOF MS has enabled large numbers of clinical samples to be analyzed simultaneously in a short time. These platforms have made "population-based proteomics" feasible for the first time (reviewed in [184]). All proteomics-based diagnostic efforts seek to identify biomarkers that, alone or in combination, can distinguish between "case" and "control" groups.

The main limitation of SELDI compared to MALDI resides in the fact that SELDI has lower resolution and lower mass accuracy. In addition, SELDI is unsuitable for high molecular weight proteins $(>100 \mathrm{kDa})$ and is limited to the detection of bound proteins on to the ProteinChip Array.

Most studies published about parasitic diseases have focused on SELDI. The SELDI, a derivation of MALDI, allows sample binding to chemically active ProteinChip surfaces. Several types of ProteinChip arrays are available with differing abilities to bind proteins with different chemical (anionic, cationic, hydrophobic, metallic, and normal phase) or biological (antibody, enzymes, receptors) properties, thereby allowing the direct analysis of proteins from complex biological samples without the need for prior separation by $2 \mathrm{D}$ gel electrophoresis. The output of the SELDI is a spectrum of mass-to-charge ratios ( $\mathrm{m}: \mathrm{z}$ values) with their corresponding relative intensities (approximating to relative abundance).

SELDI analyses were initially applied to the discovery of early diagnostic or prognostic biomarkers of cancer (reviewed in [185]). Recently, this technique has been applied to the study of serum biomarkers of infectious diseases such as Severe Acute Respiratory Syndrome [186], African trypanosomiasis [83], fascioliasis [157], cysticercosis [158], and Chagas diseases (Ndao et al., submitted). Such studies have focused on identifying a distinctive configuration of circulating serum proteins that are indicative of a specific pathophysiological state, a so-called "proteomic fingerprint."

The real potential of proteomic fingerprinting is in its use as a discovery tool for novel biomarkers that can then be incorporated into simple bedside diagnostics based on affordable technologies such as immunologically based antigen-detection tests that could be implemented in dipstick or cassette formats.

\section{Acknowledgments}

The author would like to thank the Public Health Agency of Canada and the National Microbiology Laboratory for supporting the National Reference Centre for Parasitology.

\section{References}

[1] K. Hancock and V. C. W. Tsang, "Development and optimization of the FAST-ELISA for detecting antibodies to Schistosoma mansoni," Journal of Immunological Methods, vol. 92, no. 2, pp. 167-176, 1986. 
[2] M. G. Pappas, R. Hajkowski, and W. T. Hockmeyer, "Dot enzyme-linked immunosorbent assay (Dot-ELISA): a micro technique for the rapid diagnosis of visceral leishmaniasis," Journal of Immunological Methods, vol. 64, no. 1-2, pp. 205214, 1983.

[3] M. G. Pappas, "Recent applications of the Dot-ELISA in immunoparasitology," Veterinary Parasitology, vol. 29, no. 23, pp. 105-129, 1988.

[4] S. E. Shokoples, M. Ndao, K. Kowalewska-Grochowska, and S. K. Yanow, "Multiplexed real-time PCR assay for discrimination of Plasmodium species with improved sensitivity for mixed infections," Journal of Clinical Microbiology, vol. 47, no. 4, pp. 975-980, 2009.

[5] P. D. Burbelo, R. Goldman, and T. L. Mattson, "A simplified immunoprecipitation method for quantitatively measuring antibody responses in clinical sera samples by using mammalian-produced Renilla luciferase-antigen fusion proteins," BMC Biotechnology, vol. 5, article 22, 2005.

[6] M. M. Parida, S. Sannarangaiah, P. K. Dash, P. V. L. Rao, and K. Morita, "Loop mediated isothermal amplification (LAMP): a new generation of innovative gene amplification technique; perspectives in clinical diagnosis of infectious diseases," Reviews in Medical Virology, vol. 18, no. 6, pp. 407421, 2008.

[7] K. L. Muldrew, "Molecular diagnostics of infectious diseases," Current Opinion in Pediatrics, vol. 21, no. 1, pp. 102-111, 2009.

[8] B. D. Tait, F. Hudson, L. Cantwell, et al., "Review article: luminex technology for HLA antibody detection in organ transplantation," Nephrology, vol. 14, no. 2, pp. 247-254, 2009.

[9] M. Ndao, N. Kelly, D. Normandin, et al., “Trypanosoma cruzi infection of squirrel monkeys: comparison of blood smear examination, commercial enzyme-linked immunosorbent assay, and polymerase chain reaction analysis as screening tests for evaluation of monkey-related injuries," Comparative Medicine, vol. 50, no. 6, pp. 658-665, 2000.

[10] G. R. Healy and T. K. Ruebush II, "Morphology of Babesia microti in human blood smears," American Journal of Clinical Pathology, vol. 73, no. 1, pp. 107-109, 1980.

[11] H. B. Tanowitz, L. V. Kirchhoff, D. Simon, S. A. Morris, L. M. Weiss, and M. Wittner, "Chagas' disease," Clinical Microbiology Reviews, vol. 5, no. 4, pp. 400-419, 1992.

[12] B. L. Herwaldt, "Leishmaniasis," The Lancet, vol. 354, no. 9185, pp. 1191-1199, 1999.

[13] P. Duffy and M. Fried, "Malaria: new diagnostics for an old problem," The American Journal of Tropical Medicine and Hygiene, vol. 73, no. 3, pp. 482-483, 2005.

[14] W. D. Melrose, D. D. Durrheim, and G. W. Burgess, "Update on immunological tests for lymphatic filariasis," Trends in Parasitology, vol. 20, no. 6, pp. 255-257, 2004.

[15] F. Cobo, L. Aliaga, P. Talavera, and A. Concha, "The histological spectrum of non-granulomatous localized mucosal leishmaniasis caused by Leishmania infantum," Annals of Tropical Medicine and Parasitology, vol. 101, no. 8, pp. 689694, 2007.

[16] D. J. P. Ferguson, W. M. Hutchison, and E. Pettersen, "Tissue cyst rupture in mice chronically infected with Toxoplasma gondii. An immunocytochemical and ultrastructural study," Parasitology Research, vol. 75, no. 8, pp. 599-603, 1989.

[17] T. A. Sims, J. Hay, and I. C. Talbot, "An electron microscope and immunohistochemical study of the intracellular location of Toxoplasma tissue cysts within the brains of mice with congenital toxoplasmosis," British Journal of Experimental Pathology, vol. 70, no. 3, pp. 317-325, 1989.

[18] F. Chappuis, S. Rijal, A. Soto, J. Menten, and M. Boelaert, "A meta-analysis of the diagnostic performance of the direct agglutination test and rK39 dipstick for visceral leishmaniasis," British Medical Journal, vol. 333, no. 7571, pp. 723-726, 2006.

[19] S. Ozensoy, Y. Ozbel, N. Turgay, et al., "Serodiagnosis and epidemiology of visceral leishmaniasis in Turkey," The American Journal of Tropical Medicine and Hygiene, vol. 59, no. 3, pp. 363-369, 1998.

[20] I. Cruz, C. Chicharro, J. Nieto, et al., "Comparison of new diagnostic tools for management of pediatric Mediterranean visceral leishmaniasis," Journal of Clinical Microbiology, vol. 44, no. 7, pp. 2343-2347, 2006.

[21] A. M. Croft, C. J. Jackson, H. M. Friend, and E. J. Minton, "African trypanosomiasis in a British soldier," Journal of the Royal Army Medical Corps, vol. 152, no. 3, pp. 156-160, 2006.

[22] T. S. Murray and M. Cappello, "The molecular diagnosis of parasitic diseases," Pediatric Infectious Disease Journal, vol. 27, no. 2, pp. 163-164, 2008.

[23] F. Chappuis, L. Loutan, P. Simarro, V. Lejon, and P. Buscher, "Options for field diagnosis of human African trypanosomiasis," Clinical Microbiology Reviews, vol. 18, no. 1, pp. 133146, 2005.

[24] V. Lejon, P. Buscher, E. Magnus, A. Moons, I. Wouters, and N. Van Meirvenne, "A semi-quantitative ELISA for detection of Trypanosoma brucei gambiense specific antibodies in serum and cerebrospinal fluid of sleeping sickness patients," Acta Tropica, vol. 69, no. 2, pp. 151-164, 1998.

[25] V. Lejon, J. Kwete, and P. Buscher, "Short communication: towards saliva-based screening for sleeping sickness?” Tropical Medicine and International Health, vol. 8, no. 7, pp. 585588, 2003.

[26] C. C. Loa, M. E. Adelson, E. Mordechai, I. Raphaelli, and R. C. Tilton, "Serological diagnosis of human babesiosis by IgG enzyme-linked immunosorbent assay," Current Microbiology, vol. 49, no. 6, pp. 385-389, 2004.

[27] M. Nakazawa, D. S. Rosa, V. R. A. Pereira, et al., "Excretorysecretory antigens of Trypanosoma cruzi are potentially useful for serodiagnosis of chronic Chagas' disease," Clinical and Diagnostic Laboratory Immunology, vol. 8, no. 5, pp. 1024-1027, 2001.

[28] M. Berrizbeitia, M. Ndao, J. Bubis, et al., "Purified excretedsecreted antigens from trypanosoma cruzi trypomastigotes as tools for diagnosis of Chagas' disease," Journal of Clinical Microbiology, vol. 44, no. 2, pp. 291-296, 2006.

[29] E. S. Umezawa, S. F. Bastos, J. R. Coura, et al., "An improved serodiagnostic test for Chagas' disease employing a mixture of Trypanosoma cruzi recombinant antigens," Transfusion, vol. 43, no. 1, pp. 91-97, 2003.

[30] J. F. da Silveira, E. S. Umezawa, and A. O. Luquetti, "Chagas disease: recombinant Trypanosoma cruzi antigens for serological diagnosis," Trends in Parasitology, vol. 17, no. 6, pp. 286-291, 2001.

[31] E. Beghetto, W. Buffolano, A. Spadoni, et al., "Use of an immunoglobulin $\mathrm{G}$ avidity assay based on recombinant antigens for diagnosis of primary Toxoplasma gondii infection during pregnancy," Journal of Clinical Microbiology, vol. 41, no. 12, pp. 5414-5418, 2003.

[32] G. H. Campbell, S. B. Aley, W. R. Ballou, et al., "Use of synthetic and recombinant peptides in the study of hostparasite interactions in the malarias," The American Journal 
of Tropical Medicine and Hygiene, vol. 37, no. 3, pp. 428-444, 1987.

[33] M. Salcedo, L. Barreto, M. Rojas, R. Moya, J. Cote, and M. E. Patarroyo, "Studies on the humoral immune response to a synthetic vaccine against Plasmodium falciparum malaria," Clinical and Experimental Immunology, vol. 84, no. 1, pp. 122-128, 1991.

[34] B. Courtioux, S. Bisser, P. M'Belesso, et al., "Dot enzymelinked immunosorbent assay for more reliable staging of patients with human African trypanosomiasis," Journal of Clinical Microbiology, vol. 43, no. 9, pp. 4789-4795, 2005.

[35] F. G. Araujo, "A method for demonstration of antibodies to Trypanosoma cruzi by using antigen-coated nitrocellulose paper strips," The American Journal of Tropical Medicine and Hygiene, vol. 34, no. 2, pp. 242-245, 1985.

[36] L. V. Kirchhoff, A. A. Gam, R. A. Gusmao, R. S. Goldsmith, J. M. Rezende, and A. Rassi, "Increased specificity of serodiagnosis of Chagas' disease by detection of antibody to the 72- and 90-kilodalton glycoproteins of Trypanosoma cruzi," Journal of Infectious Diseases, vol. 155, no. 3, pp. 561$564,1987$.

[37] D. A. Leiby, S. Wendel, D. T. Takaoka, R. M. Fachini, L. C. Oliveira, and M. A. Tibbals, "Serologic testing for Trypanosoma cruzi: comparison of radioimmunoprecipitation assay with commercially available indirect immunofluorescence assay, indirect hemagglutination assay, and enzymelinked immunosorbent assay kits," Journal of Clinical Microbiology, vol. 38, no. 2, pp. 639-642, 2000.

[38] E. Magnus, T. Vervoort, and N. Van Meirvenne, "A cardagglutination test with stained trypanosomes (C.A.T.T.) for the serological diagnosis of T. B. gambiense trypanosomiasis," Annales de la Société Belge de Médecine Tropicale, vol. 58, no. 3, pp. 169-176, 1978.

[39] F. Noireau, J. L. Lemesre, M. Y. Nzoukoudi, M. T. Louembet, J. P. Gouteux, and J. L. Frezil, "Serodiagnosis of sleeping sickness in the Republic of the Congo: comparison of indirect immunofluorescent antibody test and card agglutination test," Transactions of the Royal Society of Tropical Medicine and Hygiene, vol. 82, no. 2, pp. 237-240, 1988.

[40] P. J. Krause, R. Ryan, S. Telford III, D. Persing, and A. Spielman, "Efficacy of immunoglobulin M serodiagnostic test for rapid diagnosis of acute babesiosis," Journal of Clinical Microbiology, vol. 34, no. 8, pp. 2014-2016, 1996.

[41] P. J. Krause, S. R. Telford III, R. Ryan, et al., "Diagnosis of babesiosis: evaluation of a serologic test for the detection of Babesia microti antibody," Journal of Infectious Diseases, vol. 169, no. 4, pp. 923-926, 1994.

[42] A. J. Sulzer and M. Wilson, "The fluorescent antibody test for malaria," CRC Critical Reviews in Clinical Laboratory Sciences, vol. 2, no. 4, pp. 601-619, 1971.

[43] M. E. Camargo, "Improved technique of indirect immunofluorescence for serological diagnosis of toxoplasmosis," Revista do Instituto de Medicina Tropical de Sao Paulo, vol. 12, pp. 117-118, 1964.

[44] E. S. Umezawa, M. S. Nascimento, and A. M. S. Stolf, "Enzyme-linked immunosorbent assay with Trypanosoma cruzi excreted-secreted antigens (TESA-ELISA) for serodiagnosis of acute and chronic Chagas' disease," Diagnostic Microbiology and Infectious Disease, vol. 39, no. 3, pp. 169176, 2001.

[45] K. Y. Cheng, C.-D. Chang, V. A. Salbilla, et al., "Immunoblot assay using recombinant antigens as a supplemental test to confirm the presence of antibodies to Trypanosoma cruzi,"
Clinical and Vaccine Immunology, vol. 14, no. 4, pp. 355-361, 2007.

[46] V. Rilling, K. Dietz, D. Krczal, F. Knotek, and G. Enders, "Evaluation of a commercial IgG/IgM Western blot assay for early postnatal diagnosis of congenital toxoplasmosis," European Journal of Clinical Microbiology and Infectious Diseases, vol. 22, no. 3, pp. 174-180, 2003.

[47] C.-D. Chang, K. Y. Cheng, L. X. Jiang, et al., "Evaluation of a prototype Trypanosoma cruzi antibody assay with recombinant antigens on a fully automated chemiluminescence analyzer for blood donor screening," Transfusion, vol. 46, no. 10, pp. 1737-1744, 2006.

[48] A. O. Luquetti, C. Ponce, E. Ponce, et al., "Chagas' disease diagnosis: a multicentric evaluation of Chagas Stat-Pak, a rapid immunochromatographic assay with recombinant proteins of Trypanosoma cruzi," Diagnostic Microbiology and Infectious Disease, vol. 46, no. 4, pp. 265-271, 2003.

[49] C. Drakeley and H. Reyburn, "Out with the old, in with the new: the utility of rapid diagnostic tests for malaria diagnosis in Africa," Transactions of the Royal Society of Tropical Medicine and Hygiene, vol. 103, no. 4, pp. 333-337, 2009.

[50] P. J. Krause, S. Telford III, A. Spielman, et al., "Comparison of PCR with blood smear and inoculation of small animals for diagnosis of Babesia microti parasitemia," Journal of Clinical Microbiology, vol. 34, no. 11, pp. 2791-2794, 1996.

[51] D. H. Persing, D. Mathiesen, W. F. Marshall, et al., "Detection of Babesia microti by polymerase chain reaction," Journal of Clinical Microbiology, vol. 30, no. 8, pp. 2097-2103, 1992.

[52] D. R. Moser, L. V. Kirchhoff, and J. E. Donelson, "Detection of Trypanosoma cruzi by DNA amplification using the polymerase chain reaction," Journal of Clinical Microbiology, vol. 27, no. 7, pp. 1477-1482, 1989.

[53] R. Gutierrez, V. M. Angulo, Z. Tarazona, C. Britto, and O. Fernandes, "Comparison of four serological tests for the diagnosis of Chagas disease in a Colombian endemic area," Parasitology, vol. 129, no. 4, pp. 439-444, 2004.

[54] M. Diez, L. Favaloro, A. Bertolotti, et al., "Usefulness of PCR strategies for early diagnosis of Chagas' disease reactivation and treatment follow-up in heart transplantation," American Journal of Transplantation, vol. 7, no. 6, pp. 1633-1640, 2007.

[55] S. Singh, A. Dey, and R. Sivakumar, "Applications of molecular methods for Leishmania control," Expert Review of Molecular Diagnostics, vol. 5, no. 2, pp. 251-265, 2005.

[56] L. K. Erdman and K. C. Kain, "Molecular diagnostic and surveillance tools for global malaria control," Travel Medicine and Infectious Disease, vol. 6, no. 1-2, pp. 82-99, 2008.

[57] P. V. Vidigal, D. V. Santos, F. C. Castro, J. C. Couto, R. W. Vitor, and G. Brasileiro Filho, "Prenatal toxoplasmosis diagnosis from amniotic fluid by PCR," Revista da Sociedade Brasileira de Medicina Tropical, vol. 35, no. 1, pp. 1-6, 2002.

[58] M. H. Bessieres, A. Berrebi, S. Cassaing, et al., "Diagnosis of congenital toxoplasmosis: prenatal and neonatal evaluation of methods used in Toulouse University Hospital and incidence of congenital toxoplasmosis," Memorias do Instituto Oswaldo Cruz, vol. 104, no. 2, pp. 389-392, 2009.

[59] S. Becker, J. R. Franco, P. P. Simarro, A. Stich, P. M. Abel, and D. Steverding, "Real-time PCR for detection of Trypanosoma brucei in human blood samples," Diagnostic Microbiology and Infectious Disease, vol. 50, no. 3, pp. 193-199, 2004.

[60] S. Bretagne, R. Durand, M. Olivi, et al., "Real-time PCR as a new tool for quantifying Leishmania infantum in liver in infected mice," Clinical and Diagnostic Laboratory Immunology, vol. 8, no. 4, pp. 828-831, 2001. 
[61] C. Mary, F. Faraut, L. Lascombe, and H. Dumon, "Quantification of Leishmania infantum DNA by a real-time PCR assay with high sensitivity," Journal of Clinical Microbiology, vol. 42, no. 11, pp. 5249-5255, 2004.

[62] N. Rolao, S. Cortes, O. R. Rodrigues, and L. Campino, "Quantification of Leishmania infantum parasites in tissue biopsies by real-time polymerase chain reaction and polymerase chain reaction-enzyme-linked immunosorbent assay," Journal of Parasitology, vol. 90, no. 5, pp. 1150-1154, 2004.

[63] S. Romand, M. Chosson, J. Franck, et al., "Usefulness of quantitative polymerase chain reaction in amniotic fluid as early prognostic marker of fetal infection with Toxoplasma gondii," American Journal of Obstetrics and Gynecology, vol. 190, no. 3, pp. 797-802, 2004.

[64] W. F. van der Meide, G. J. Schoone, W. R. Faber, et al., "Quantitative nucleic acid sequence-based assay as a new molecular tool for detection and quantification of Leishmania parasites in skin biopsy samples," Journal of Clinical Microbiology, vol. 43, no. 11, pp. 5560-5566, 2005.

[65] G. J. Schoone, L. Oskam, N. C. M. Kroon, H. D. F. H. Schallig, and S. A. Omar, "Detection and quantification of Plasmodium falciparum in blood samples using quantitative nucleic acid sequence-based amplification," Journal of Clinical Microbiology, vol. 38, no. 11, pp. 4072-4075, 2000.

[66] S. A. Omar, P. F. Mens, G. J. Schoone, et al., "Plasmodium falciparum: evaluation of a quantitative nucleic acid sequence-based amplification assay to predict the outcome of sulfadoxine-pyrimethamine treatment of uncomplicated malaria," Experimental Parasitology, vol. 110, no. 1, pp. 7379, 2005.

[67] P. F. Mens, G. J. Schoone, P. A. Kager, and H. D. F. H. Schallig, "Detection and identification of human Plasmodium species with real-time quantitative nucleic acid sequence-based amplification," Malaria Journal, vol. 5, article 80, 2006.

[68] Z. K. Njiru, A. S. J. Mikosza, E. Matovu, et al., "African trypanosomiasis: sensitive and rapid detection of the subgenus Trypanozoon by loop-mediated isothermal amplification (LAMP) of parasite DNA," International Journal for Parasitology, vol. 38, no. 5, pp. 589-599, 2008.

[69] O. M. M. Thekisoe, N. Kuboki, A. Nambota, et al., "Speciesspecific loop-mediated isothermal amplification (LAMP) for diagnosis of trypanosomosis," Acta Tropica, vol. 102, no. 3, pp. 182-189, 2007.

[70] L. L. M. Poon, B. W. Y. Wong, E. H. T. Ma, et al., "Sensitive and inexpensive molecular test for falciparum malaria: defecting Plasmodium falciparum DNA directly from heattreated blood by loop-mediated isothermal amplification," Clinical Chemistry, vol. 52, no. 2, pp. 303-306, 2006.

[71] E.-T. Han, R. Watanabe, J. Sattabongkot, et al., "Detection of four Plasmodium species by genus- and species-specific loop-mediated isothermal amplification for clinical diagnosis," Journal of Clinical Microbiology, vol. 45, no. 8, pp. 25212528, 2007.

[72] D. H. Paris, M. Imwong, A. M. Faiz, et al., "Loop-mediated isothermal PCR (LAMP) for the diagnosis of falciparum malaria," The American Journal of Tropical Medicine and Hygiene, vol. 77, no. 5, pp. 972-976, 2007.

[73] H. Aonuma, M. Suzuki, H. Iseki, et al., "Rapid identification of Plasmodium-carrying mosquitoes using loopmediated isothermal amplification," Biochemical and Biophysical Research Communications, vol. 376, no. 4, pp. 671676, 2008.
[74] M. Yamamura, K. Makimura, and Y. Ota, "Evaluation of a new rapid molecular diagnostic system for Plasmodium falciparum combined with DNA filter paper, loopmediated isothermal amplification, and melting curve analysis," Japanese Journal of Infectious Diseases, vol. 62, no. 1, pp. 20-25, 2009.

[75] D. T. McNamara, L. J. Kasehagen, B. T. Grimberg, J. ColeTobian, W. E. Collins, and P. A. Zimmerman, "Diagnosing infection levels of four human malaria parasite species by a polymerase chain reaction/ligase detection reaction fluorescent microsphere-based assay," The American Journal of Tropical Medicine and Hygiene, vol. 74, no. 3, pp. 413-421, 2006.

[76] S. De Doncker, V. Hutse, S. Abdellati, et al., "A new PCRELISA for diagnosis of visceral leishmaniasis in blood of HIVnegative subjects," Transactions of the Royal Society of Tropical Medicine and Hygiene, vol. 99, no. 1, pp. 25-31, 2005.

[77] A. Humar, M. A. Harrington, and K. C. Kain, "Evaluation of a non-isotopic polymerase chain reaction-based assay to detect and predict treatment failure of Plasmodium vivax malaria in travellers," Transactions of the Royal Society of Tropical Medicine and Hygiene, vol. 91, no. 4, pp. 406-409, 1997.

[78] K. J. Y. Zhong and K. C. Kain, "Evaluation of a colorimetric PCR-based assay to diagnose Plasmodium falciparum malaria in travelers," Journal of Clinical Microbiology, vol. 37, no. 2, pp. 339-341, 1999.

[79] A. Calderaro, G. Piccolo, C. Zuelli, et al., "Evaluation of a new plate hybridization assay for the laboratory diagnosis of imported malaria in Italy," New Microbiologica, vol. 27, no. 2, pp. 163-171, 2004.

[80] S. Deborggraeve, F. Claes, T. Laurent, et al., "Molecular dipstick test for diagnosis of sleeping sickness," Journal of Clinical Microbiology, vol. 44, no. 8, pp. 2884-2889, 2006.

[81] R. Reithinger and J.-C. Dujardin, "Molecular diagnosis of leishmaniasis: current status and future applications," Journal of Clinical Microbiology, vol. 45, no. 1, pp. 21-25, 2007.

[82] D. Agranoff, A. Stich, P. Abel, and S. Krishna, "Proteomic fingerprinting for the diagnosis of human African trypanosomiasis," Trends in Parasitology, vol. 21, no. 4, pp. 154-157, 2005.

[83] M. C. Papadopoulos, P. M. Abel, D. Agranoff, et al., "A novel and accurate diagnostic test for human African trypanosomiasis," The Lancet, vol. 363, no. 9418, pp. 13581363, 2004.

[84] M. Nyunt, J. Pisciotta, A. B. Feldman, et al., "Detection of Plasmodium falciparum in pregnancy by laser desorption mass spectrometry," The American Journal of Tropical Medicine and Hygiene, vol. 73, no. 3, pp. 485-490, 2005.

[85] P. A. Demirev, A. B. Feldman, D. Kongkasuriyachai, P. Scholl, D. Sullivan Jr., and N. Kumar, "Detection of malaria parasites in blood by laser desorption mass spectrometry," Analytical Chemistry, vol. 74, no. 14, pp. 3262-3266, 2002.

[86] P. F. Scholl, D. Kongkasuriyachai, P. A. Demirev, et al., "Rapid detection of malaria infection in vivo by laser desorption mass spectrometry," The American Journal of Tropical Medicine and Hygiene, vol. 71, no. 5, pp. 546-551, 2004.

[87] R. J. ten Hove, M. van Esbroeck, T. Vervoort, J. van den Ende, L. van Lieshout, and J. J. Verweij, "Molecular diagnostics of intestinal parasites in returning travellers," European Journal of Clinical Microbiology and Infectious Diseases, vol. 28, no. 9, pp. 1045-1053, 2009.

[88] M. Cordova, L. Reategui, and J. R. Espinoza, "Immunodiagnosis of human fascioliasis with Fasciola hepatica cysteine 
proteinases," Transactions of the Royal Society of Tropical Medicine and Hygiene, vol. 93, no. 1, pp. 54-57, 1999.

[89] N. Katz, A. Chaves, and J. Pellegrino, "A simple device for quantitative stool thick-smear technique in Schistosomiasis mansoni," Revista do Instituto de Medicina Tropical de Sao Paulo, vol. 14, no. 6, pp. 397-400, 1972.

[90] W. Zhang and D. P. McManus, "Recent advances in the immunology and diagnosis of echinococcosis," FEMS Immunology and Medical Microbiology, vol. 47, no. 1, pp. 2441, 2006.

[91] R. Chandrashekar, K. C. Curtis, R. M. Ramzy, F. Liftis, B.W. Li, and G. J. Weil, "Molecular cloning of Brugia malayi antigens for diagnosis of lymphatic filariasis," Molecular and Biochemical Parasitology, vol. 64, no. 2, pp. 261-271, 1994.

[92] A. A. Siddiqui and S. L. Berk, "Diagnosis of Strongyloides stercoralis infection," Clinical Infectious Diseases, vol. 33, no. 7, pp. 1040-1047, 2001.

[93] T. Weitzel, S. Dittrich, I. Mohl, E. Adusu, and T. Jelinek, "Evaluation of seven commercial antigen detection tests for Giardia and Cryptosporidium in stool samples," Clinical Microbiology and Infection, vol. 12, no. 7, pp. 656-659, 2006.

[94] M. T. Katanik, S. K. Schneider, J. E. Rosenblatt, G. S. Hall, and G. W. Procop, "Evaluation of ColorPAC Giardia/Cryptosporidium rapid assay and ProSpect Giardia/Cryptosporidium microplate assay for detection of Giardia and Cryptosporidium in fecal specimens," Journal of Clinical Microbiology, vol. 39, no. 12, pp. 4523-4525, 2001.

[95] J. R. Espinoza, V. Maco, L. Marcos, et al., "Evaluation of FAS2-ELISA for the serological detection of Fasciola hepatica infection in humans," The American Journal of Tropical Medicine and Hygiene, vol. 76, no. 5, pp. 977-982, 2007.

[96] A. Rabello, "Diagnosing schistosomiasis," Memorias do Instituto Oswaldo Cruz, vol. 92, no. 5, pp. 669-676, 1997.

[97] J. Pardo, J. L. P. Arellano, R. Lopez-Velez, C. Carranza, M. Cordero, and A. Muro, "Application of an ELISA test using Schistosoma bovis adult worm antigens in travellers and immigrants from a schistosomiasis endemic area and its correlation with clinical findings," Scandinavian Journal of Infectious Diseases, vol. 39, no. 5, pp. 435-440, 2007.

[98] N. Rosas, J. Sotelo, and D. Nieto, "ELISA in the diagnosis of neurocysticercosis," Archives of Neurology, vol. 43, no. 4, pp. 353-356, 1986.

[99] J. C. Allan, G. Avila, J. Garcia Noval, A. Flisser, and P. S. Craig, "Immunodiagnosis of taeniasis by coproantigen detection," Parasitology, vol. 101, no. 3, pp. 473-477, 1990.

[100] H. H. Garcia, R. M. E. Parkhouse, R. H. Gilman, et al., "Serum antigen detection in the diagnosis, treatment, and follow-up of neurocysticercosis patients," Transactions of the Royal Society of Tropical Medicine and Hygiene, vol. 94, no. 6, pp. 673-676, 2000.

[101] E. C. Bueno, C. M. Scheel, A. J. Vaz, et al., "Application of synthetic $8-\mathrm{kD}$ and recombinant GP50 antigens in the diagnosis of neurocysticercosis by enzyme-linked immunosorbent assay," The American Journal of Tropical Medicine and Hygiene, vol. 72, no. 3, pp. 278-283, 2005.

[102] B. Gottstein, "Molecular and immunological diagnosis of echinococcosis," Clinical Microbiology Reviews, vol. 5, no. 3, pp. 248-261, 1992.

[103] V. G. Virginio, A. Hernandez, M. B. Rott, et al., "A set of recombinant antigens from Echinococcus granulosus with potential for use in the immunodiagnosis of human cystic hydatid disease," Clinical and Experimental Immunology, vol. 132, no. 2, pp. 309-315, 2003.
[104] A. M. Qaqish, M. A. Nasrieh, K. M. Al-Qaoud, P. S. Craig, and S. K. Abdel-Hafez, "The seroprevalences of cystic echinococcosis, and the associated risk factors, in ruralagricultural, bedouin and semi-bedouin communities in Jordan," Annals of Tropical Medicine and Parasitology, vol. 97, no. 5, pp. 511-520, 2003.

[105] A. Hernández, G. Cardozo, S. Dematteis, et al., "Cystic echinococcosis: analysis of the serological profile related to the risk factors in individuals without ultrasound liver changes living in an endemic area of Tacuarembó, Uruguay," Parasitology, vol. 130, no. 4, pp. 455-460, 2005.

[106] D. Carmena, A. Benito, and E. Eraso, "The immunodiagnosis of Echinococcus multilocularis infection," Clinical Microbiology and Infection, vol. 13, no. 5, pp. 460-475, 2007.

[107] R. M. Genta, "Predictive value of an enzyme-linked immunosorbent assay (ELISA) for the serodiagnosis of strongyloidiasis," American Journal of Clinical Pathology, vol. 89, no. 3, pp. 391-394, 1988.

[108] D. J. Conway, N. S. Atkins, J. E. Lillywhite, et al., "Immunodiagnosis of Strongyloides stercoralis infection: a method for increasing the specificity of the indirect ELISA," Transactions of the Royal Society of Tropical Medicine and Hygiene, vol. 87, no. 2, pp. 173-176, 1993.

[109] F. M. de Paula, E. de Castro, M. Gonçalves-Pires, M. Marçal, D. M. Campos, and J. M. Costa-Cruz, "Parasitological and immunological diagnoses of strongyloidiasis in immunocompromised and non-immunocompromised children at Uberlândia, State of Minas Gerais, Brazil," Revista do Instituto de Medicina Tropical de Sao Paulo, vol. 42, no. 1, pp. 51-55, 2000.

[110] M. R. Loutfy, M. Wilson, J. S. Keystone, and K. C. Kain, "Serology and eosinophil count in the diagnosis and management of strongyloidiasis in a non-endemic area," The American Journal of Tropical Medicine and Hygiene, vol. 66, no. 6, pp. 749-752, 2002.

[111] S. Lim, K. Katz, S. Krajden, M. Fuksa, J. S. Keystone, and K. C. Kain, "Complicated and fatal Strongyloides infection in Canadians: risk factors, diagnosis and management," Canadian Medical Association Journal, vol. 171, no. 5, pp. 479-484, 2004.

[112] G. V. Hillyer, M. S. de Galanes, J. Rodriguez-Perez, et al., "Use of the Falcon" ${ }^{\mathrm{TM}}$ assay screening test-enzymelinked immunosorbent assay (FAST-ELISA) and the enzymelinked immunoelectrotransfer blot (EITB) to determine the prevalence of human fascioliasis in the Bolivian Altiplano," The American Journal of Tropical Medicine and Hygiene, vol. 46, no. 5, pp. 603-609, 1992.

[113] N. Kumar, S. Ghosh, and S. C. Gupta, "Early detection of Fasciola gigantica infection in buffaloes by enzyme-linked immunosorbent assay and dot enzyme-linked immunosorbent assay," Parasitology Research, vol. 103, no. 1, pp. 141150, 2008.

[114] G. L. Zimmerman, M. J. Nelson, and C. R. B. Clark, "Diagnosis of ovine fascioliasis by a dot enzyme-linked immunosorbent assay: a rapid microdiagnostic technique," American Journal of Veterinary Research, vol. 46, no. 7, pp. 1513-1515, 1985.

[115] A. L. T. Rabbello, M. M. A. Garcia, E. Dias Neto, R. S. Rocha, and N. Katz, "Dot-dye-immunoassay and dotELISA for the serological differentiation of acute and chronic schistosomiasis mansoni using keyhole limpet haemocyanin as antigen," Transactions of the Royal Society of Tropical Medicine and Hygiene, vol. 87, no. 3, pp. 279-281, 1993. 
[116] M. G. Pappas, P. M. Schantz, L. T. Cannon Sr., and S. P. Wahlquist, "Dot-ELISA for the rapid serodiagnosis of human hydatid disease," Diagnostic Immunology, vol. 4, no. 6, pp. 271-276, 1986.

[117] M. M. Al-Sherbiny, A.-A. M. M. K. Farrag, M. H. Fayad, M. K. Makled, G. M. Tawfeek, and N. M. S. Ali, "Application and assessment of a dipstick assay in the diagnosis of hydatidosis and trichinosis," Parasitology Research, vol. 93, no. 2, pp. 8795, 2004.

[118] P. J. Lammie, G. Weil, R. Noordin, et al., "Recombinant antigen-based antibody assays for the diagnosis and surveillance of lymphatic filariasis-a multicenter trial," Filaria Journal, vol. 3, no. 1, article 9, 2004.

[119] M. Jamail, K. Andrew, D. Junaidi, A. K. Krishnan, M. Faizal, and N. Rahmah, "Field validation of sensitivity and specificity of rapid test for detection of Brugia malayi infection," Tropical Medicine and International Health, vol. 10, no. 1, pp. 99-104, 2005.

[120] N. Rahmah, S. Taniawati, R. K. Shenoy, et al., "Specificity and sensitivity of a rapid dipstick test (Brugia Rapid) in the detection of Brugia malayi infection," Transactions of the Royal Society of Tropical Medicine and Hygiene, vol. 95, no. 6, pp. 601-604, 2001.

[121] T. van Gool, H. Vetter, T. Vervoort, M. J. Doenhoff, J. Wetsteyn, and D. Overbosch, "Serodiagnosis of imported schistosomiasis by a combination of a commercial indirect hemagglutination test with Schistosoma mansoni adult worm antigens and an enzyme-linked immunosorbent assay with S. mansoni egg antigens," Journal of Clinical Microbiology, vol. 40, no. 9, pp. 3432-3437, 2002.

[122] M. A. Nasrieh and S. K. Abdel-Hafez, "Echinococcus granulosus in Jordan: assessment of various antigenic preparations for use in the serodiagnosis of surgically confirmed cases using enzyme immuno assays and the indirect haemagglutination test," Diagnostic Microbiology and Infectious Disease, vol. 48, no. 2, pp. 117-123, 2004.

[123] G. J. Weil, P. J. Lammie, and N. Weiss, "The ICT filariasis test: a rapid-format antigen test for diagnosis of bancroftian filariasis," Parasitology Today, vol. 13, no. 10, pp. 401-404, 1997.

[124] Y. Sato, H. Toma, S. Kiyuna, and Y. Shiroma, "Gelatin particle indirect agglutination test for mass examination for strongyloidiasis," Transactions of the Royal Society of Tropical Medicine and Hygiene, vol. 85, no. 4, pp. 515-518, 1991.

[125] L. S. Garcia and R. Y. Shimizu, "Evaluation of nine immunoassay kits (enzyme immunoassay and direct fluorescence) for detection of Giardia lamblia and Cryptosporidium parvum in human fecal specimens," Journal of Clinical Microbiology, vol. 35, no. 6, pp. 1526-1529, 1997.

[126] L. S. Garcia, A. C. Shum, and D. A. Bruckner, "Evaluation of a new monoclonal antibody combination reagent for direct fluorescence detection of Giardia cysts and Cryptosporidium oocysts in human fecal specimens," Journal of Clinical Microbiology, vol. 30, no. 12, pp. 3255-3257, 1992.

[127] J. M. Costa-Cruz, C. B. Hullamah, M. R. Gonçalves-Pires, D. M. B. Campos, and M. A. Vieira, "Cryo-microtome sections of coproculture larvae of strongyloides stercoralis and strongyloides raft/as antigen sources for the immunodiagnosis of human strongyloidiasis," Revista do Instituto de Medicina Tropical de Sao Paulo, vol. 39, no. 6, pp. 313-317, 1997.

[128] E. R. Machado, M. T. Ueta, M. R. Gonçalves-Pires, J. B. Alves de Oliveira, L. H. Faccioli, and J. M. CostaCruz, "Diagnosis of human strongyloidiasis using particulate antigen of two strains of Strongyloides venezuelensis in indirect immunofluorescence antibody test," Experimental Parasitology, vol. 99, no. 1, pp. 52-55, 2001.

[129] M. M. Al-Sherbiny, A. M. Osman, K. Hancock, A. M. Deelder, and V. C. W. Tsang, "Application of immunodiagnostic assays: detection of antibodies and circulating antigens in human schistosomiasis and correlation with clinical findings," The American Journal of Tropical Medicine and Hygiene, vol. 60, no. 6, pp. 960-966, 1999.

[130] V. C. W. Tsang, J. A. Brand, and A. E. Boyer, "An enzyme-linked immunoelectrotransfer blot assay and glycoprotein antigens for diagnosing human cysticercosis (Taenia solium)," Journal of Infectious Diseases, vol. 159, no. 1, pp. 5059, 1989.

[131] P. P. Wilkins, J. C. Allan, M. Verastegui, et al., "Development of a serologic assay to detect Taenia solium taeniasis," The American Journal of Tropical Medicine and Hygiene, vol. 60, no. 2, pp. 199-204, 1999.

[132] L. P. Silva, I. S. Da Costa Barcelos, A. B. Passos-Lima, F. S. Espindola, D. M. Barbosa Campos, and J. M. Costa-Cruz, "Western blotting using Strongyloides ratti antigen for the detection of IgG antibodies as confirmatory test in human strongyloidiasis," Memorias do Instituto Oswaldo Cruz, vol. 98, no. 5, pp. 687-691, 2003.

[133] P. D. Burbelo, R. Ramanathan, A. D. Klion, M. J. Iadarola, and T. B. Nutman, "Rapid, novel, specific, high-throughput assay for diagnosis of Loa loa infection," Journal of Clinical Microbiology, vol. 46, no. 7, pp. 2298-2304, 2008.

[134] R. Ramanathan, P. D. Burbelo, S. Groot, M. J. Iadarola, F. A. Neva, and T. B. Nutman, "A luciferase immunoprecipitation systems assay enhances the sensitivity and specificity of diagnosis of Strongyloides stercoralis infection," Journal of Infectious Diseases, vol. 198, no. 3, pp. 444-451, 2008.

[135] D. W. Johnson, N. J. Pieniazek, D. W. Griffin, L. Misener, and J. B. Rose, "Development of a PCR protocol for sensitive detection of Cryptosporidium oocysts in water samples," Applied and Environmental Microbiology, vol. 61, no. 11, pp. 3849-3855, 1995.

[136] U. M. Morgan, C. C. Constantine, D. A. Forbes, and R. C. A. Thompson, "Differentiation between human and animal isolates of Cryptosporidium parvum using rDNA sequencing and direct PCR analysis," Journal of Parasitology, vol. 83, no. 5, pp. 825-830, 1997.

[137] F. G. C. Abath, A. L. D. V. Gomes, F. L. Melo, C. S. Barbosa, and R. P. Werkhauser, "Molecular approaches for the detection of Schistosoma mansoni: possible applications in the detection of snail infection, monitoring of transmission sites, and diagnosis of human infection," Memorias do Instituto Oswaldo Cruz, vol. 101, supplement 1, pp. 145-148, 2006.

[138] L. A. Pontes, E. Dias-Neto, and A. Rabello, "Detection by polymerase chain reaction of Schistosoma mansoni DNA in human serum and feces," The American Journal of Tropical Medicine and Hygiene, vol. 66, no. 2, pp. 157-162, 2002.

[139] L. M. Gonzalez, E. Montero, S. Puente, et al., "PCR tools for the differential diagnosis of Taenia saginata and Taenia solium taeniasis/cysticercosis from different geographical locations," Diagnostic Microbiology and Infectious Disease, vol. 42, no. 4, pp. 243-249, 2002.

[140] H. Yamasaki, M. Nakao, Y. Sako, K. Nakaya, M. O. Sato, and A. Ito, "Mitochondrial DNA diagnosis for taeniasis and cysticercosis," Parasitology International, vol. 55, supplement 1, pp. S81-S85, 2006.

[141] R. M. Ramzy, "Field application of PCR-based assays for monitoring Wuchereria bancrofti infection in Africa," Annals 
of Tropical Medicine and Parasitology, vol. 96, supplement 2, pp. S55-S59, 2002.

[142] M. Zhong, J. McCarthy, L. Bierwert, et al., "A polymerase chain reaction assay for detection of the parasite Wuchereria bancrofti in human blood samples," The American Journal of Tropical Medicine and Hygiene, vol. 54, no. 4, pp. 357-363, 1996.

[143] S. A. Williams, L. Nicolas, M. Lizotte-Waniewski, et al., "A polymerase chain reaction assay for the detection of Wuchereria bancrofti in blood samples from French Polynesia," Transactions of the Royal Society of Tropical Medicine and Hygiene, vol. 90, no. 4, pp. 384-387, 1996.

[144] S. Ramachandran, A. A. Gam, and F. A. Neva, "Molecular differences between several species of Strongyloides and comparison of selected isolates of $\mathrm{S}$. stercoralis using a polymerase chain reaction-linked restriction fragment length polymorphism approach," The American Journal of Tropical Medicine and Hygiene, vol. 56, no. 1, pp. 61-65, 1997.

[145] J. R. Limor, A. A. Lal, and L. Xiao, "Detection and differentiation of Cryptosporidium parasites that are pathogenic for humans by real-time PCR," Journal of Clinical Microbiology, vol. 40, no. 7, pp. 2335-2338, 2002.

[146] R. ten Hove, T. Schuurman, M. Kooistra, L. Möller, L. van Lieshout, and J. J. Verweij, "Detection of diarrhoea-causing protozoa in general practice patients in The Netherlands by multiplex real-time PCR," Clinical Microbiology and Infection, vol. 13, no. 10, pp. 1001-1007, 2007.

[147] N. Jothikumar, A. J. da Silva, I. Moura, Y. Qvarnstrom, and V. R. Hill, "Detection and differentiation of Cryptosporidium hominis and Cryptosporidium parvum by dual TaqMan assays," Journal of Medical Microbiology, vol. 57, no. 9, pp. 1099-1105, 2008.

[148] R. J. ten Hove, J. J. Verweij, K. Vereecken, K. Polman, L. Dieye, and L. van Lieshout, "Multiplex real-time PCR for the detection and quantification of Schistosoma mansoni and S. haematobium infection in stool samples collected in northern Senegal," Transactions of the Royal Society of Tropical Medicine and Hygiene, vol. 102, no. 2, pp. 179-185, 2008.

[149] A. L. D. V. Gomes, F. L. Melo, R. P. Werkhauser, and F. G. C. Abath, "Development of a real time polymerase chain reaction for quantitation of Schistosoma mansoni DNA," Memorias do Instituto Oswaldo Cruz, vol. 101, supplement 1, pp. 133-136, 2006.

[150] J. J. Verweij, M. Canales, K. Polman, et al., "Molecular diagnosis of Strongyloides stercoralis in faecal samples using real-time PCR," Transactions of the Royal Society of Tropical Medicine and Hygiene, vol. 103, no. 4, pp. 342-346, 2009.

[151] P. Karanis, O. Thekisoe, K. Kiouptsi, J. Ongerth, I. Igarashi, and N. Inoue, "Development and preliminary evaluation of a loop-mediated isothermal amplification procedure for sensitive detection of Cryptosporidium oocysts in fecal and water samples," Applied and Environmental Microbiology, vol. 73, no. 17, pp. 5660-5662, 2007.

[152] M. A. Bakheit, D. Torra, L. A. Palomino, et al., "Sensitive and specific detection of Cryptosporidium species in PCRnegative samples by loop-mediated isothermal DNA amplification and confirmation of generated LAMP products by sequencing," Veterinary Parasitology, vol. 158, no. 1-2, pp. 1122, 2008.

[153] A. Nkouawa, Y. Sako, M. Nakao, K. Nakaya, and A. Ito, "Loop-mediated isothermal amplification method for differentiation and rapid detection of Taenia species," Journal of Clinical Microbiology, vol. 47, no. 1, pp. 168-174, 2009.
[154] K. Bandyopadhyay, K. L. Kellar, I. Moura, et al., "Rapid microsphere assay for identification of Cryptosporidium hominis and Cryptosporidium parvum in stool and environmental samples," Journal of Clinical Microbiology, vol. 45, no. 9, pp. 2835-2840, 2007.

[155] P. Fischer, X. Liu, M. Lizotte-Waniewski, I. H. Kamal, R. M. R. Ramzy, and S. A. Williams, "Development of a quantitative, competitive polymerase chain reaction-enzymelinked immunosorbent assay for the detection of Wuchereria bancrofti DNA," Parasitology Research, vol. 85, no. 3, pp. 176183, 1999.

[156] O. P. Akinwale, T. Laurent, P. Mertens, et al., "Detection of schistosomes polymerase chain reaction amplified DNA by oligochromatographic dipstick," Molecular and Biochemical Parasitology, vol. 160, no. 2, pp. 167-170, 2008.

[157] M.-C. Rioux, C. Carmona, D. Acosta, et al., "Discovery and validation of serum biomarkers expressed over the first twelve weeks of Fasciola hepatica infection in sheep," International Journal for Parasitology, vol. 38, no. 1, pp. 123136, 2008.

[158] N. Deckers, P. Dorny, K. Kanobana, et al., "Use of ProteinChip technology for identifying biomarkers of parasitic diseases: the example of porcine cysticercosis (Taenia solium)," Experimental Parasitology, vol. 120, no. 4, pp. 320329, 2008.

[159] W. J. Carter, Z. Yan, N. D. Cassai, and G. S. Sidhu, "Detection of extracellular forms of babesia in the blood by electron microscopy: a diagnostic method for differentiation from Plasmodium falciparum," Ultrastructural Pathology, vol. 27, no. 4, pp. 211-216, 2003.

[160] S. E. Maddison, "The present status of serodiagnosis and seroepidemiology of schistosomiasis," Diagnostic Microbiology and Infectious Disease, vol. 7, no. 2, pp. 93-105, 1987.

[161] R. C. Ko and T. F. Ng, "Evaluation of excretory/secretory products of larval Taenia solium as diagnostic antigens for porcine and human cysticercosis," Journal of Helminthology, vol. 72, no. 2, pp. 147-154, 1998.

[162] A. Prasad, A. Nasir, and N. Singh, "Detection of antiHaemonchus contortus antibodies in sheep by dot-ELISA with immunoaffinity purified fraction of ES antigen during prepatency," Indian Journal of Experimental Biology, vol. 46, no. 2, pp. 94-99, 2008.

[163] S. Kumar, R. Kumar, A. K. Gupta, and S. K. Dwivedi, "Passive transfer of Theileria equi antibodies to neonate foals of immune tolerant mares," Veterinary Parasitology, vol. 151, no. 1, pp. 80-85, 2008.

[164] H. J. Carrasco, A. Torrellas, C. Garcia, M. Segovia, and M. D. Feliciangeli, "Risk of Trypanosoma cruzi I (Kinetoplastida: Trypanosomatidae) transmission by Panstrongylus geniculatus (Hemiptera: Reduviidae) in Caracas (Metropolitan District) and neighboring States, Venezuela," International Journal for Parasitology, vol. 35, no. 13, pp. 1379-1384, 2005.

[165] C. K. Murray, R. A. Gasser Jr., A. J. Magill, and R. S. Miller, "Update on rapid diagnostic testing for malaria," Clinical Microbiology Reviews, vol. 21, no. 1, pp. 97-110, 2008.

[166] A. D. C. Vexenat, J. M. Santana, and A. R. L. Teixeira, "Cross-reactivity of antibodies in human infections by the kinetoplastid protozoa Trypanosoma cruzi, Leishmania chagasi and Leishmania (Viannia) braziliensis," Revista do Instituto de Medicina Tropical de Sao Paulo, vol. 38, no. 3, pp. 177-185, 1996.

[167] B. Singh, "Molecular methods for diagnosis and epidemiological studies of parasitic infections," International Journal for Parasitology, vol. 27, no. 10, pp. 1135-1145, 1997. 
[168] P. Moro and P. M. Schantz, "Echinococcosis: a review," International Journal of Infectious Diseases, vol. 13, no. 2, pp. 125-133, 2009.

[169] P. Mens, N. Spieker, S. Omar, M. Heijnen, H. Schallig, and P. A. Kager, "Is molecular biology the best alternative for diagnosis of malaria to microscopy? A comparison between microscopy, antigen detection and molecular tests in rural Kenya and urban Tanzania," Tropical Medicine and International Health, vol. 12, no. 2, pp. 238-244, 2007.

[170] D. S. Zarlenga and J. Higgins, "PCR as a diagnostic and quantitative technique in veterinary parasitology," Veterinary Parasitology, vol. 101, no. 3-4, pp. 215-230, 2001.

[171] R. B. Gasser, "Molecular tools-advances, opportunities and prospects," Veterinary Parasitology, vol. 136, no. 2, pp. 69-89, 2006.

[172] G. A. Farcas, R. Soeller, K. Zhong, A. Zahirieh, and K. C. Kain, "Real-time polymerase chain reaction assay for the rapid detection and characterization of chloroquine-resistant Plasmodium falciparum malaria in returned travelers," Clinical Infectious Diseases, vol. 42, no. 5, pp. 622-627, 2006.

[173] S. Bretagne and J.-M. Costa, "Towards a nucleic acid-based diagnosis in clinical parasitology and mycology," Clinica Chimica Acta, vol. 363, no. 1-2, pp. 221-228, 2006.

[174] T. Notomi, H. Okayama, H. Masubuchi, et al., "Loopmediated isothermal amplification of DNA," Nucleic Acids Research, vol. 28, no. 12, p. E63, 2000.

[175] M. Parida, G. Posadas, S. Inoue, F. Hasebe, and K. Morita, "Real-time reverse transcription loop-mediated isothermal amplification for rapid detection of West Nile virus," Journal of Clinical Microbiology, vol. 42, no. 1, pp. 257-263, 2004.

[176] L. L. M. Poon, B. W. Y. Wong, K. H. Chan, et al., "Evaluation of real-time reverse transcriptase PCR and real-time loopmediated amplification assays for severe acute respiratory syndrome coronavirus detection," Journal of Clinical Microbiology, vol. 43, no. 7, pp. 3457-3459, 2005.

[177] S. Y. Liang, Y. H. Chan, K. T. Hsia, et al., "Development of loop-mediated isothermal amplification assay for detection of Entamoeba histolytica," Journal of Clinical Microbiology, vol. 47, no. 6, pp. 1892-1895, 2009.

[178] A. Alhassan, O. M. M. Thekisoe, N. Yokoyama, et al., "Development of loop-mediated isothermal amplification (LAMP) method for diagnosis of equine piroplasmosis," Veterinary Parasitology, vol. 143, no. 2, pp. 155-160, 2007.

[179] G. Guan, A. Chauvin, J. Luo, et al., "The development and evaluation of a loop-mediated isothermal amplification (LAMP) method for detection of Babesia spp. infective to sheep and goats in China," Experimental Parasitology, vol. 120, no. 1, pp. 39-44, 2008.

[180] H. Aonuma, A. Yoshimura, N. Perera, et al., "Loop-mediated isothermal amplification applied to filarial parasites detection in the mosquito vectors: Dirofilaria immitis as a study model," Parasites and Vectors, vol. 2, no. 1, article 15, 2009.

[181] Y. Mori, K. Nagamine, N. Tomita, and T. Notomi, "Detection of loop-mediated isothermal amplification reaction by turbidity derived from magnesium pyrophosphate formation," Biochemical and Biophysical Research Communications, vol. 289, no. 1, pp. 150-154, 2001.

[182] H. Iseki, A. Alhassan, N. Ohta, et al., "Development of a multiplex loop-mediated isothermal amplification (mLAMP) method for the simultaneous detection of bovine Babesia parasites," Journal of Microbiological Methods, vol. 71, no. 3, pp. 281-287, 2007.
[183] S. A. Dunbar, "Applications of Luminex xMAP technology for rapid, high-throughput multiplexed nucleic acid detection," Clinica Chimica Acta, vol. 363, no. 1-2, pp. 71-82, 2006.

[184] N. Tang, P. Tornatore, and S. R. Weinberger, "Current developments in SELDI affinity technology," Mass Spectrometry Reviews, vol. 23, no. 1, pp. 34-44, 2004.

[185] Z. Xiao, D. Prieto, T. P. Conrads, T. D. Veenstra, and H. J. Issaq, "Proteomic patterns: their potential for disease diagnosis," Molecular and Cellular Endocrinology, vol. 230, no. 1-2, pp. 95-106, 2005.

[186] R. T. K. Pang, T. C. W. Poon, K. C. A. Chan, et al., "Serum proteomic fingerprints of adult patients with severe acute respiratory syndrome," Clinical Chemistry, vol. 52, no. 3, pp. 421-429, 2006. 


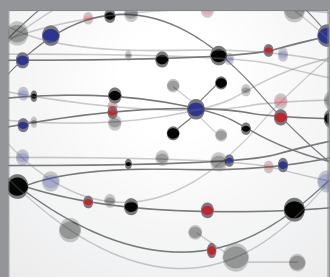

The Scientific World Journal
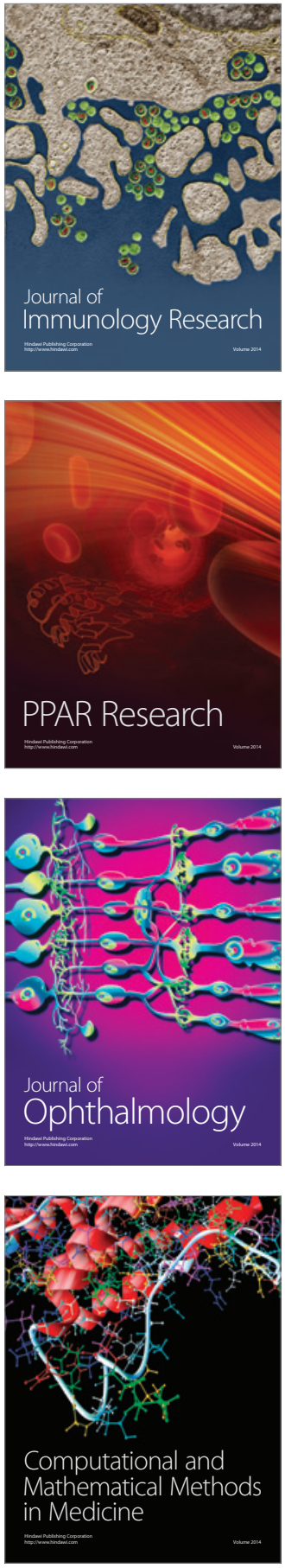

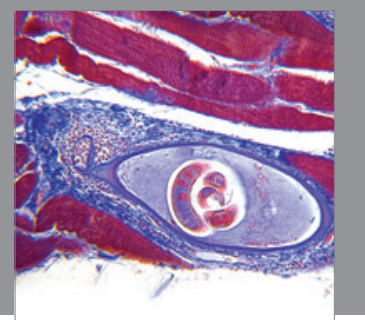

Gastroenterology

Research and Practice
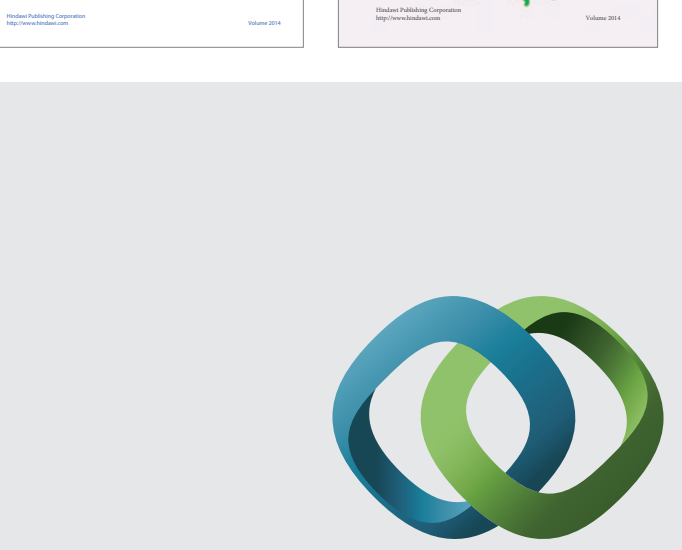

\section{Hindawi}

Submit your manuscripts at

http://www.hindawi.com


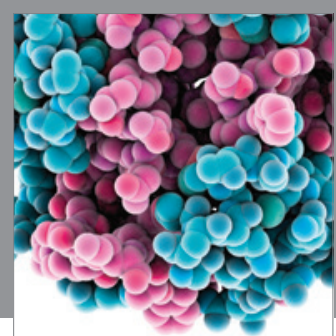

Journal of
Diabetes Research

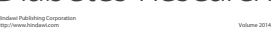

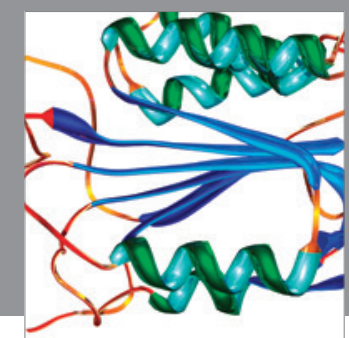

Disease Markers
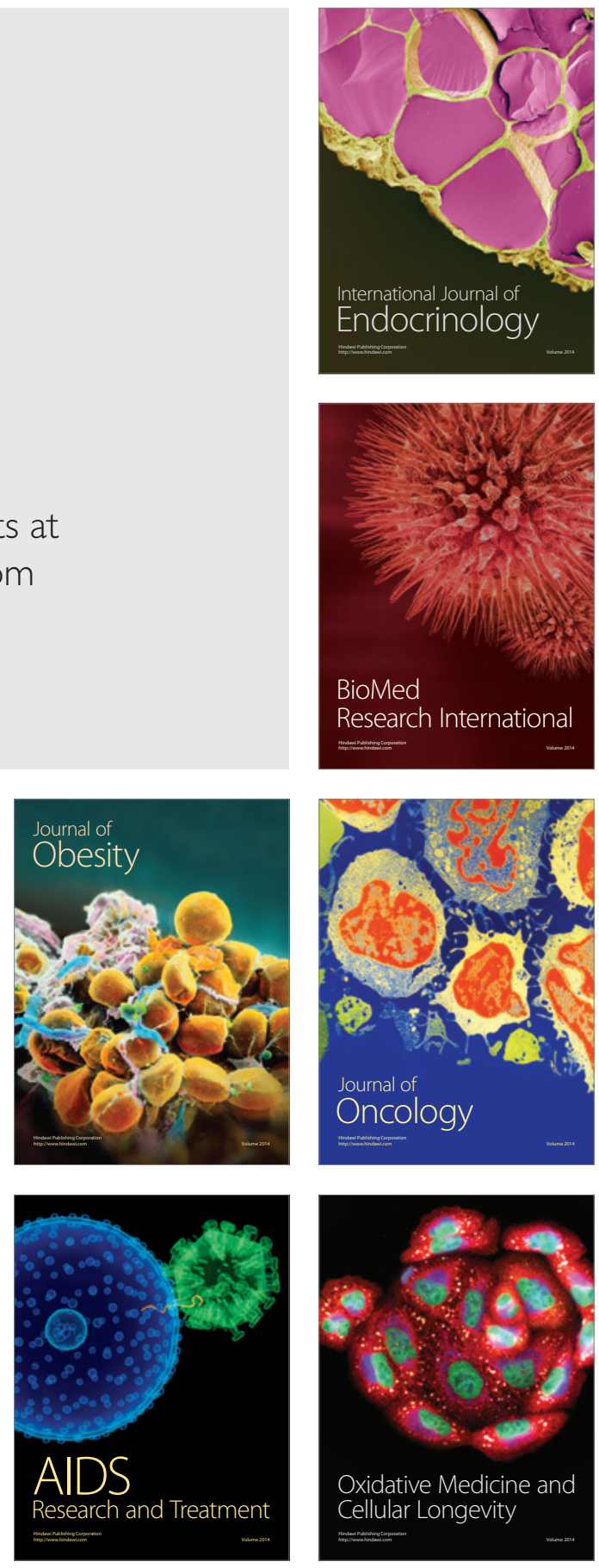